\title{
Recent Advances in Isolated Single-Atom Catalysts for Zinc Air Batteries: A Focus Review
}

\author{
Weimin Zhang ${ }^{1}$, Yuqing Liu ${ }^{2}$, Lipeng Zhang ${ }^{1, *}$ and Jun Chen ${ }^{2, *} \mathbb{C}$ \\ 1 School of Chemistry and Chemical Engineering, Shandong University of Technology, Zibo 255049, China; \\ wmzhang@sdut.edu.cn \\ 2 ARC Centre of Excellence for Electromaterials Science, Intelligent Polymer Research Institute, Australian \\ Institute of Innovative Materials, Innovation Campus, University of Wollongong, \\ Wollongong, NSW 2522, Australia; yuqing@uow.edu.au \\ * Correspondence: zhanglipeng@sdut.edu.cn (L.Z.); junc@uow.edu.au (J.C.)
}

Received: 5 September 2019; Accepted: 26 September 2019; Published: 2 October 2019

check for updates

\begin{abstract}
Recently, zinc-air batteries (ZABs) have been receiving attention due to their theoretically high energy density, excellent safety, and the abundance of zinc resources. Typically, the performance of the zinc air batteries is determined by two catalytic reactions on the cathode-the oxygen reduction reaction (ORR) and the oxygen evolution reaction (OER). Therefore, intensive effort has been devoted to explore high performance electrocatalysts with desired morphology, size, and composition. Among them, single-atom catalysts (SACs) have emerged as attractive and unique systems because of their high electrocatalytic activity, good durability, and $100 \%$ active atom utilization. In this review, we mainly focus on the advance application of SACs in zinc air batteries in recent years. Firstly, SACs are briefly compared with catalysts in other scales (i.e., micro- and nano-materials). A main emphasis is then focused on synthesis and electrocatalytic activity as well as the underlying mechanisms for mono- and dual-metal-based SACs in zinc air batteries catalysis. Finally, a prospect is provided that is expected to guide the rational design and synthesis of SACs for zinc air batteries.
\end{abstract}

Keywords: Single-atom catalysis; zinc-air battery; oxygen reduction

\section{Introduction}

\subsection{Why ZABs?}

Nowadays, based on the current advanced technology, the energy density of lithium ion batteries can reach only approximately 100 250 $\mathrm{Wh} \mathrm{kg}^{-1}$. Therefore, it is urgent and critical to develop alternative chemical power sources to satisfy the increasing demands of various portable and stational electric devices. Among various newly developed post-lithium-ion battery technologies, metal-air batteries have the potential to provide several times higher performance than the current advanced lithium ion batteries (in terms of gravimetric energy density) and have therefore been regarded as promising candidates to power various electric devices.

Typically, metal-air batteries are fuel cells comprised of a metal anode (like $\mathrm{Li}, \mathrm{Na}, \mathrm{K}, \mathrm{Mg}, \mathrm{Al}, \mathrm{Zn}$, and $\mathrm{Fe}$ ), an air electrode, a proper amount of electrolytes, and a separator [1-10]. In terms of full cell voltage, the alkali metal-air batteries have the highest values of 2.96, 2.33, and $2.48 \mathrm{~V}$ for Li-air, Na-air, and K-air batteries, respectively, which are higher than those other metal-air batteries. The theoretical energy density for diverse metal-air batteries and the Ragone plots for some important and mostly investigated metal-air batteries are given in Figure 1. We can see that among the various metal-air batteries, lithium-air batteries possess a high theoretical specific mass energy density, up to 11,430 Wh $\mathrm{kg}^{-1}$ (excluding oxygen uptake). However, due to the low mass densities of the alkali metals, the 
corresponding volume energy densities of $\mathrm{Li}$-air, Na-air, and $\mathrm{K}$-air are 6104, 2634, and $1513 \mathrm{Wh} \mathrm{L}^{-1}$, respectively, which are lower than zinc-air batteries $\left(9653 \mathrm{Wh} \mathrm{L}^{-1}\right)$ and other metal-air batteries. [11] In addition, their serve hazard issues significantly limit their practical applications [10]. For other metal-air batteries, Al can be easily dissolved in either alkaline or acid electrolytes, which greatly impedes the application of aluminum-air batteries. $\mathrm{Mg}$-air and $\mathrm{Al}$-air batteries suffer from rapid self-discharge via the hydrogen evolution reaction due to the low standard electrode potentials of $\mathrm{Mg}(-2.372 \mathrm{~V}$ vs. Reversible Hydrogen Electrode (RHE)) and $\mathrm{Al}(-1.662 \mathrm{~V}$ vs. RHE). In addition, both of them are not electrically rechargeable. Compared to the above-mentioned metal-air batteries, zinc-air batteries exhibit a high specific capability, a high theoretical high energy, excellent safety, high corrosion resistance and an earth abundance of zinc metal anode. These merits probably make them the most practically viable battery systems.

a

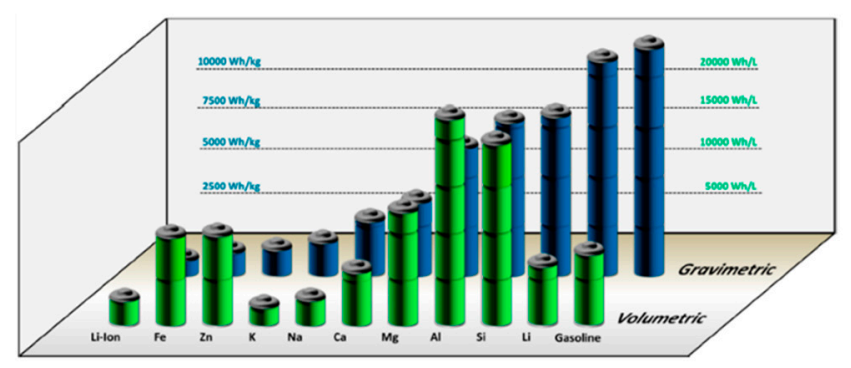

b

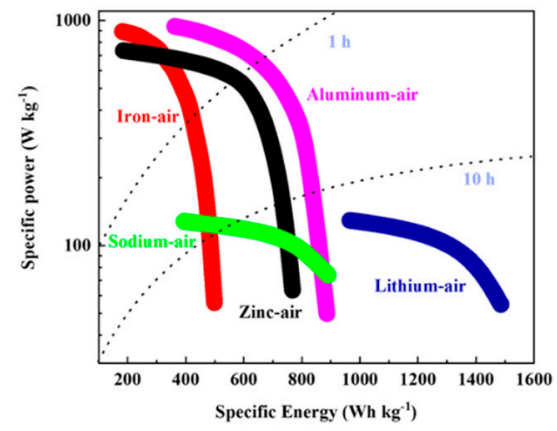

Figure 1. Theoretical energy of various metal-air batteries (excluding oxygen uptake) (a) and the Ragone plots for some important and established metal-air batteries (b) [11].

\subsection{Working Principle of $\mathrm{ZABs}$}

There are three main types of zinc-air batteries (ZABs), namely primary, secondary and mechanically rechargeable batteries. A primary ZAB is applied for single use and is then discarded after the metal anode is completely consumed. A secondary rechargeable battery system is returned to its original state by forcing current in the reverse direction versus that of the discharge. In a mechanically rechargeable $\mathrm{ZAB}$, the depleted anode and failure electrolyte are replaced to repeatedly recover the capacity for the battery, so mechanically rechargeable ZABs are a class of refurbishable primary cells.

According to the type of electrolyte, ZABs can be categorized into aqueous and non-aqueous types. The corresponding electrolytes are alkaline solutions and solid polymer electrolytes (SPEs) or room temperature ionic liquids (RTILs). Among them, aqueous ZABs (especially those using the $\mathrm{KOH}$ electrolyte) are the most mature and reliable battery system $[12,13]$. In an alkaline primary ZAB, as shown in Figure 2a, the zinc metal is oxidized at the air electrode with an electron release during the discharge process. The resulting $\mathrm{Zn}^{2+}$ further reacts with the $\mathrm{OH}^{-}$diffused from the cathode, which generates soluble zincate ions $\left(\mathrm{Zn}(\mathrm{OH})_{4}{ }^{2-}\right)$. The zincate ions are increasingly supersaturated upon the battery discharge and then decomposed into insoluble $\mathrm{ZnO}$. The electrons pass through the electric circuit and provide electric energy to various electric devices. Simultaneously, $\mathrm{O}_{2}$ accepts the electrons generated from the anode, and the oxygen reduction reaction (ORR) occurs, which yields $\mathrm{OH}^{-}$. Since zinc is an active metal and self-corrosion is unavoidable, $\mathrm{Zn}(\mathrm{OH})_{2}$ and $\mathrm{H}_{2}$ are yieled. Typically, the detailed reactions in the discharge process for an alkaline $\mathrm{ZAB}$ are summarized as the follows.

Anode:

$$
\begin{gathered}
\mathrm{Zn}+4 \mathrm{OH}^{-} \rightarrow \mathrm{Zn}(\mathrm{OH})_{4}{ }^{2-}+2 \mathrm{e}^{-} \\
\mathrm{Zn}(\mathrm{OH})_{4}{ }^{2-} \rightarrow \mathrm{ZnO}+\mathrm{H}_{2} \mathrm{O}+2 \mathrm{OH}^{-}
\end{gathered}
$$

Cathode:

$$
\mathrm{O}_{2}+2 \mathrm{H}_{2} \mathrm{O}+4 \mathrm{e}^{-} \rightarrow 4 \mathrm{OH}^{-}
$$


Total reaction:

$$
2 \mathrm{Zn}+\mathrm{O}_{2} \rightarrow 2 \mathrm{ZnO}
$$

Parasitic reaction:

$$
\mathrm{Zn}+2 \mathrm{H}_{2} \mathrm{O} \rightarrow \mathrm{Zn}(\mathrm{OH})_{2}+\mathrm{H}_{2}
$$

In terms of the electrochemical reactions, both primary and mechanically rechargeable ZABs operate only in a discharge mode which involves the above-mentioned electrochemical reactions. For a secondary rechargeable $\mathrm{ZAB}$, however, a charge process is also involved which is fulfilled by reversing the reactions (Figure 2b). The corresponding reactions include the oxygen evolution reaction (OER) at the air electrode and the zinc metal plating at the negative electrode.
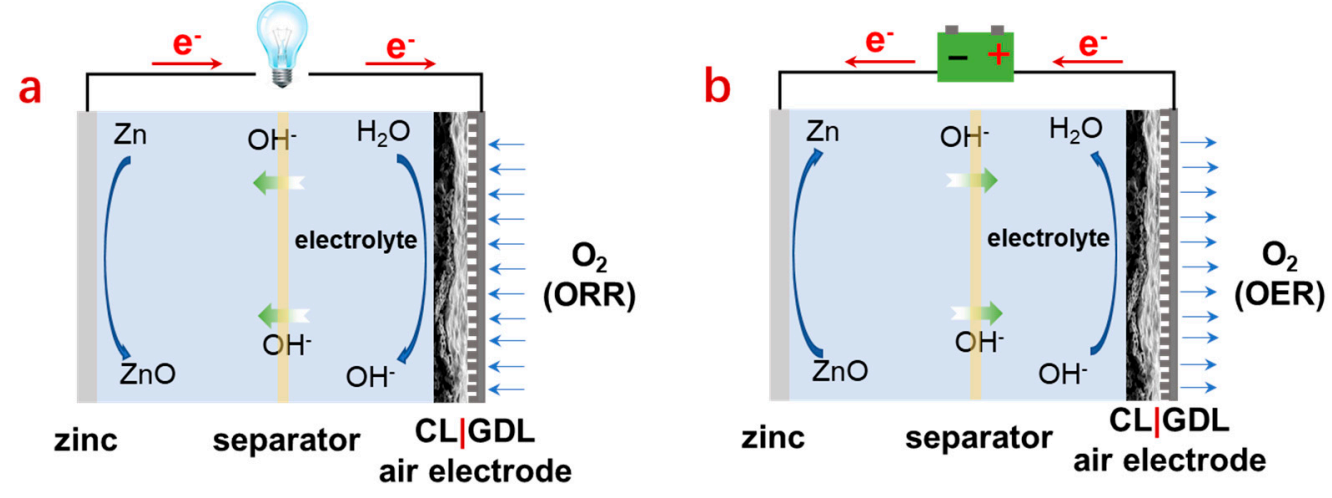

\section{CL-catalyst layer \\ GDL-gas diffusion layer}

Figure 2. Schematic illustration of configuration of zinc-air batteries (ZABs) and their working principle in the discharge (a) and charge (b) processes.

\subsection{Challenges and Opportunities}

In recent years, $\mathrm{ZABs}$ have been receiving much attention and achieving great progress. It is worth mentioning that primary ZABs have been commercially implemented for telecommunication and medical applications. However, despite their primary commercialization and promising potential, the development of ZABs has been impeded by the main issues associated with the metal and air electrodes. In addition, issues including non-uniform zinc dissolution and deposition, as well as the lack of a satisfactory bifunctional electrocatalyst, have greatly impeded the cyclability of secondary ZABs. Despite the high theoretical voltage of $1.66 \mathrm{~V}$ created by the thermodynamically spontaneous cathodic and anodic reactions, the practical operation voltage is normally less than $1.2 \mathrm{~V}$. Moreover, to re-charge a $\mathrm{ZAB}$, a much higher voltage of $2 \mathrm{~V}$ is often required to reverse the reactions. This voltage is mainly raised by the large electrode polarizations of the ORR and the OER at the air electrode and the parasitic oxidation of the $\mathrm{Zn}$ metal, as well as its dendritic growth at the $\mathrm{Zn}$ electrode. To improve the ORR/OER performance and maximum the energy output efficiency as well as the long-term cyclability for ZABs, effort has been continuously dedicated to exploring highly active electrocatalysts for their air electrode reactions. Thus far, many electrocatalyst including precious metals and alloys [14-16], hetero-atoms doped carbonaceous materials [17-20], transition metals and their carbides and oxides [21-23], and perovskite materials [24] have been developed. For more efficient and enhanced electrocatalysts, common strategies include tuning the particle size, morphology, crystalline facets, electronic structure, and hybridization to a rational state [25-28]. For perovskite materials, anion-deficient tuning is an effective strategy to enhance their ionic conductivity, which may further improve their ORR/OER performance [29-32]. Among all strategies, downsizing the catalyst particle is the most effective and straightforward one to increase the catalytic active sites while also increasing the under-coordinated 
metal atoms sites. Theoretically, a maximum utilization of $100 \%$ of metal atoms can be reached when the size is reduced to an atomic scale, which corresponds to single atom catalysts (SACs). In the past several years, SACs have attracted much attention in catalysis science due to their boosted catalytic activity, selectivity, stability, and the reduced utilization of their active metals [33-39].

In this review, we limit the scope to the recent advances of SACs for ZABs. Emphasis is focused on the discussion of the synthetic methodologies and the electrocatalytic activity as well as the underlying mechanisms of SACs for the ORR/OER in ZABs.

\section{SACs in ZABs}

SACs are materials with isolated atomic metal active sites dispersed on a support at an atomic state. The concepts of single-atom catalysis and single-atom catalyst were pioneered by Zhang and co-workers in 2011. They synthesized single Pt atoms on $\mathrm{FeO}_{\mathrm{x}}$ for the catalysis of $\mathrm{CO}$ oxidation. Due to the alteration of the electronic structure of $\mathrm{Pt}$ and the charge transfer from $\mathrm{Pt}$ to $\mathrm{FeO}_{\mathrm{x}}$, the single-atom catalyst exhibited exceptional catalytic activity and stability [36]. A single-atom catalyst possesses many distinguished properties which are different from those of its nanostructured or sub-nanostructured countparts. For example, when the dispersion level of the atoms in the catalyst reach atom scale, there is a sharp increase in surface apparent energy, quantum size effect, and unsaturated coordination environment, as well as a different interaction between the metal and the support. Due to the fact that only the coordinately unsaturated atoms on the surface of catalysts can be involved in the catalytic process, all these resulted characters endow the catalyst with superior catalytic performance compared with their bulky and nanostructured counterparts. In addition, according to Figure 3, SACs inherit the merits of both heterogeneous and homogeneous catalysts. In catalyzing the ORR/OER in ZABs, it is expected that single-atom catalysis exhibits the potential to make best use of the advantages while also bypassing the disadvantages of heterogeneous and homogenous catalysis [32-35].

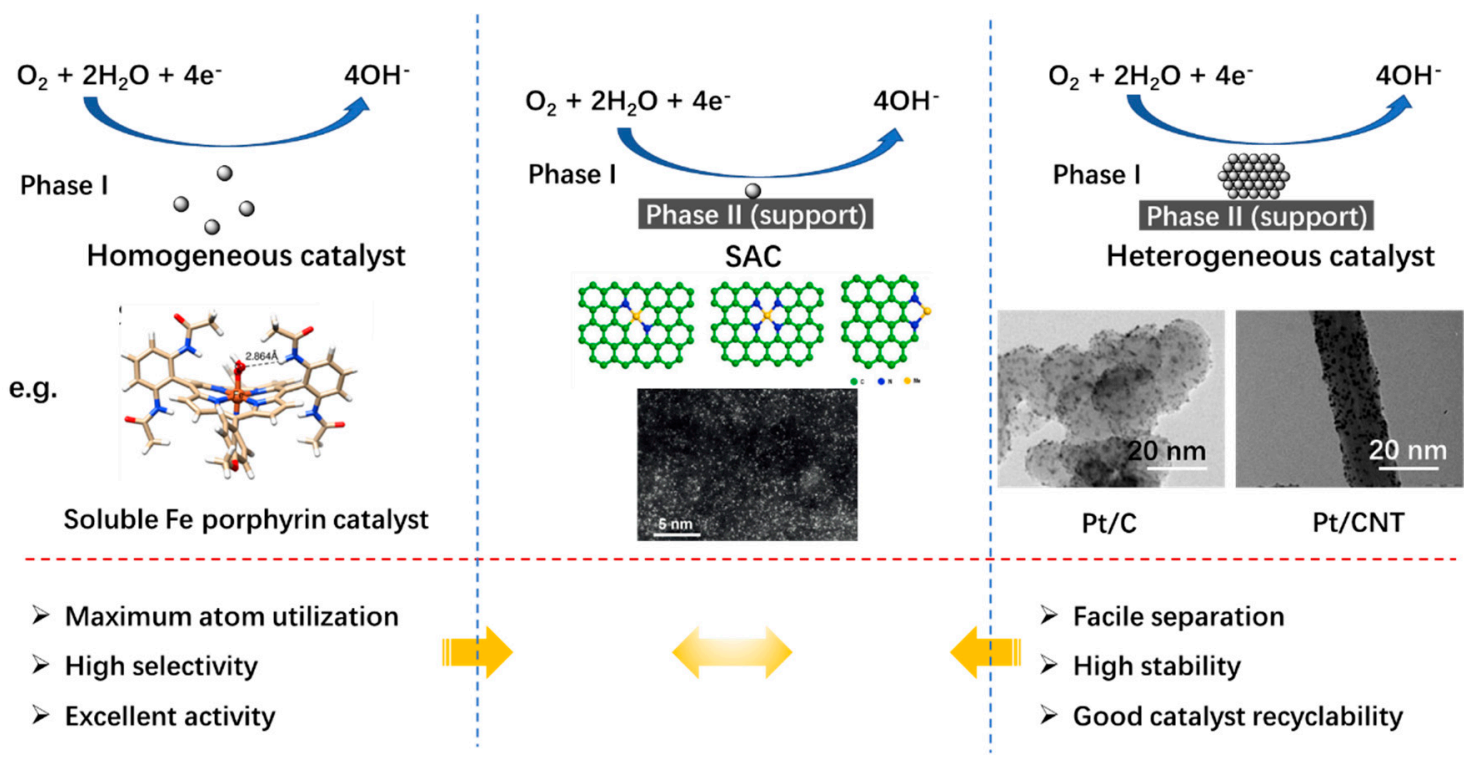

Figure 3. Comparison of diverse catalysis systems for the oxygen reduction reaction (ORR) in alkaline media and the corresponding merits for the corresponding catalysts. The pictures were adopted from [40-43].

The most extensively studied and effective SACs for ZABs are $M-N_{x} / C(M=F e, C o, M n, C u$, etc.; $x=2,4,6$, etc.) supported on a carbonaceous matrix. The $M_{x}-N / C$ catalysts are usually those with the isolated active metal centers dispersed on a support and stabilized by covalent coordination or the interaction of neighboring surface atoms such as nitrogen, oxygen or sulfur. The average order of the ORR/OER activity of the $\mathrm{MN}_{\mathrm{x}}$-based SACs is Fe- $\mathrm{N}_{\mathrm{x}} / \mathrm{C}>\mathrm{Co}-\mathrm{N}_{\mathrm{x}} / \mathrm{C}>\mathrm{Mn}-\mathrm{N}_{\mathrm{x}} / \mathrm{C}>$ 
$\mathrm{Cu}-\mathrm{N}_{\mathrm{x}} / \mathrm{C}$ [44-55]. The low cost $\mathrm{M}-\mathrm{N}_{\mathrm{x}} / \mathrm{C}$ catalysts that use diverse transition metals as their centers exhibit outstanding catalytic activity for the ORR/OER in ZABs and have been regarded as alternatives to Pt-based catalysts $[50-52,56,57]$. Though there is no $\mathrm{M}-\mathrm{M}$ bond to break the $\mathrm{O}-\mathrm{O}$ bond for $\mathrm{M}-\mathrm{N}_{\mathrm{x}}$ moiety-based SACs, $\mathrm{M}-\mathrm{N}_{\mathrm{x}}-\mathrm{C}$-based catalysts can promote the ORR with a high performance through a four-electron pathway. It has been suggested that these catalysts' highly dispersed as well as coordinatively unsaturated environment and enhanced charge-transfer effect by the interaction of the metal-support remarkably increase catalytic active sites. Their unique electronic structures also result in the appropriate adsorption energies for oxygen and thus decrease the free energies, all of which eventually leads to improved intrinsic catalytic activity and the four-electron pathway for the ORR $[58,59]$. In addition, owing to the fact that metal centers are confined by heteroatoms in the carbon matrix, their electrocatalytic stability is significantly enhanced. Thus far, among the diverse non-noble metals, Fe and $\mathrm{Co}$ are the most commonly employed metals used to construct $\mathrm{M}-\mathrm{N}_{\mathrm{x}}$ moiety sites and have been proven to perform best for various electrochemical catalytic reactions [37,60-65].

\section{Advances of SACs in ZABs}

\section{1. $\mathrm{Fe}-\mathrm{N}_{x} / \mathrm{C}$-Based SACs}

\subsubsection{Mono-Metal Fe- $\mathrm{N}_{\mathrm{x}} / \mathrm{C}-$-Based SACs}

Generally, it has been established that $\mathrm{Fe}-\mathrm{N}_{\mathrm{x}} / \mathrm{C}$ intrinsically perform best for the ORR among the various $N-M_{x} / C$ SACs because of the stronger adsorption of $\mathrm{O}_{2}$ on the $\mathrm{Fe}-\mathrm{N}_{\mathrm{x}}$ moiety than other moieties [59]. To synthesize $\mathrm{Fe}-\mathrm{N}_{\mathrm{x}} / \mathrm{C}$, previous synthesis methodologies usually use pyrolyzing iron-based macrocycle complexes or a simply mixed precursor containing iron and a nitrogen source. These methods often involve a wet impregnation procedure and a subsequent heat treatment at temperatures ranging from 650 to $1000{ }^{\circ} \mathrm{C}$ in an inert atmosphere [66]. One of the drawbacks is that this is likely to result in the formation of inert metal particles and oxides or other less active species. Therefore, metal loading must be kept $<1 \mathrm{wt} \%$ to avoid aggregation during synthesis [53]. Due to the lack of sufficient active sites, the catalytic activity is quite low. For example, ZABs with a low loading of a $0.26 \% \mathrm{Fe}-\mathrm{N}_{\mathrm{x}} / \mathrm{C}$ catalyst can only deliver a maximum power density of $\sim 70 \mathrm{~mW} \mathrm{~cm}^{-2}$ and a specific capacity of $705 \mathrm{mAh} \mathrm{g}^{-1}$ at $5 \mathrm{~mA} \mathrm{~cm}^{-2}$ [53].

The most effective approach to enhance the performance of SACs is probably to increase the density of active sites on the support while promoting the intrinsic activity of the active sites. To increase the number of active sites, the well-established and most often employed synthetic methodologies are based on defect engineering, spatial confinement strategies, and coordination design strategies [67]. When these strategies are rationally used in synthesis, a much higher metal loading may be obtained. For example, Yang et al. used a versatile molecule-confined pyrolysis strategy based on the wet-chemical method and successfully synthesized a single Fe atom-based SAC (Fe-SAs/N-C) with a high metal loading up to $3.5 \mathrm{wt} \%$ on a porous $\mathrm{N}$-doped carbon matrix. In their study, they first confined the $\mathrm{Fe}^{2+}$ by coordinating it to 1,10-phenanthroline (phen) ligand and then using this coordinated system as the precursor. Due to the space isolation effect of the phen, the subsequent pyrolysis resulted in single Fe atoms rather than Fe nanoparticles. The as-synthesized catalyst exhibited a better electrochemical performance that of a commercial $\mathrm{Pt} / \mathrm{C}$ catalyst for the ORR in a $0.1 \mathrm{M} \mathrm{KOH}$ aqueous electrolyte. In this work, they clarified that the mechanism of the catalytic activity is mainly derived from isolated atomic $\mathrm{Fe}-\mathrm{N}_{\mathrm{x}}$ moiety sites other than $\mathrm{C}-\mathrm{N}_{\mathrm{x}}$. Benefiting from this, a three-cell primary zinc-air battery stacked with an $\mathrm{Fe}-\mathrm{N}_{4} / \mathrm{C}$ catalyst delivered a high maximum power density of $225 \mathrm{~mW} \mathrm{~cm}^{-2}$, and the specific capacity was $\sim 636 \mathrm{mAh} \mathrm{g}^{-1}$ (Figure 4) [68]. 
a

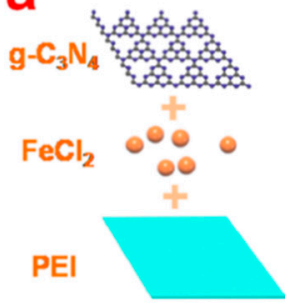

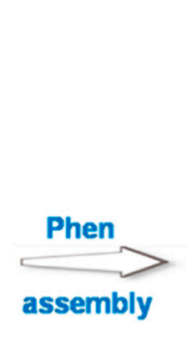

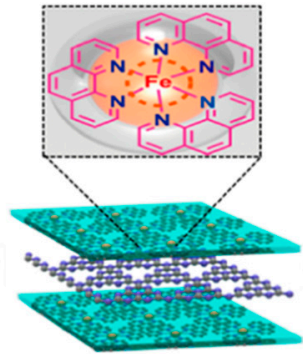

pyrolysis
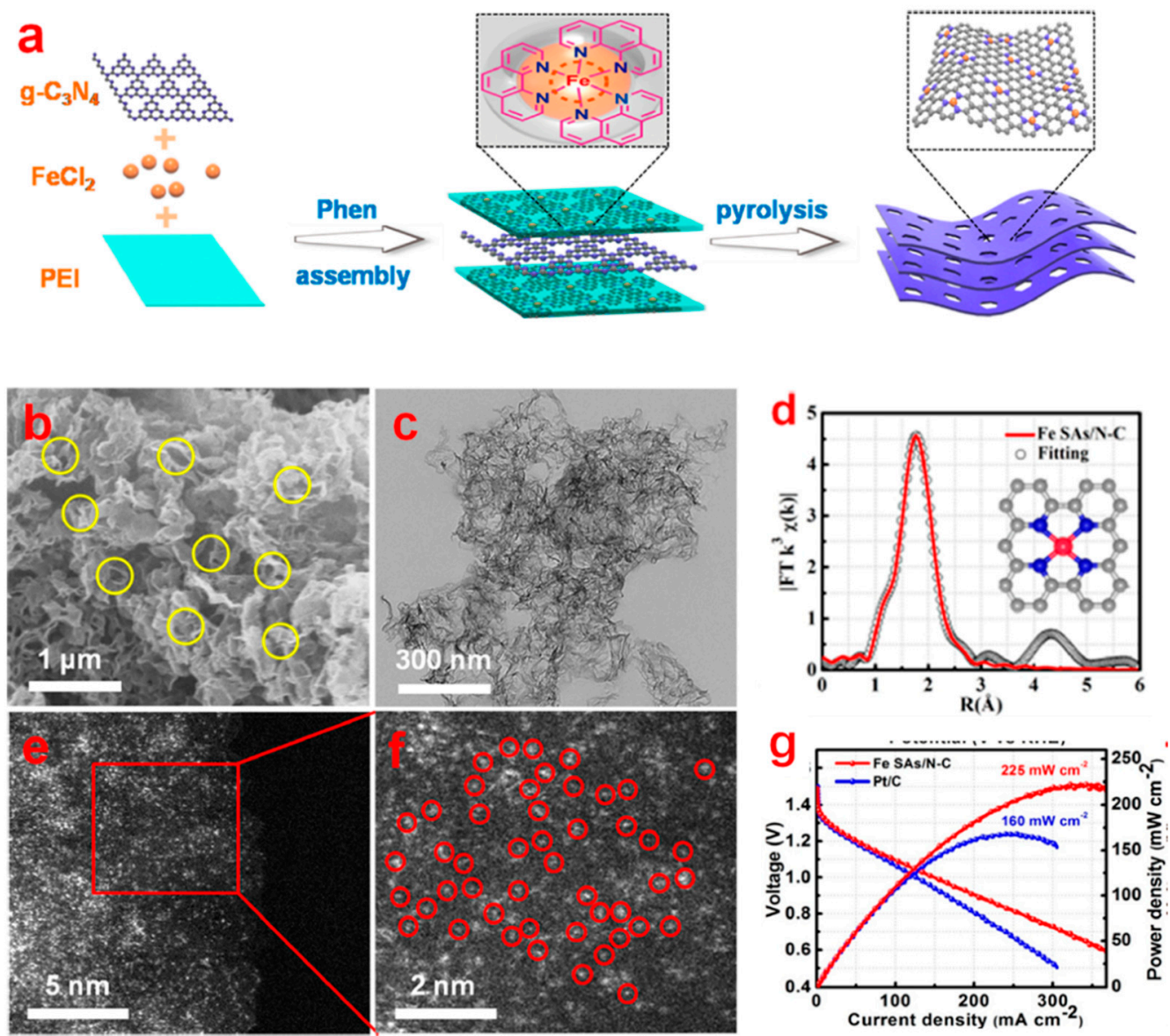

Figure 4. Schematic illustration of the synthetic strategy for single Fe atoms on porous N-doped carbon (Fe-SAs/N-C) (a), SEM image (b), Transmission Electron Microscope (TEM) image (c), Fourier transforms Extended X-ray fine structure (FT-EXAFS) fitting curve and the proposed atomic structure model (d), aberration-corrected high-angle annular dark-field scanning TEM (AC HAADF-STEM) images $(\mathbf{e}, \mathbf{f})$, and polarization curves in a zinc-air batteries $(\mathbf{g})$ [68].

Additionally, to obtain a high loading SAC, metal-organic framework (MOF)-based materials have been employed to assist the spatial confinement strategy. MOFs exhibit well-defined porous structures which can act as the spatial separation and confinement of the single metal atom loading. The highly ordered arranged organic linkers can be readily converted into a functional carbon support, and the metal species can be changed into a single metal-based active site after pyrolysis. Therefore, MOFs have great potential in synthesizing diverse metal-based SACs for the ORR/OER [46,69-72].

\subsubsection{Dual-Metal Fe- $\mathrm{N}_{\mathrm{x}} / \mathrm{C}$-Based SACs}

Recent reports have indicated that introducing a different metal atom into Co or Fe SACs can more effectively facilitate the cleavage of oxygen-oxygen bonds to achieve a four-electron pathway during the ORR and to feature enhanced catalytic activity [73-75]. In such a structure, the center metal is coordinated with a foreign metal atom instead of being coordinated with nitrogen in the common simple single atom, leading to a structure such as Fe-Co and $\mathrm{Zn}-\mathrm{Co}$. For example, in the an $\mathrm{Fe}-\mathrm{Co}$ system (Figure 5), the strong binding of an oxygen molecule on the dual site enables the sufficient activation of $\mathrm{O}-\mathrm{O}$ from 1.23 to $1.40 \AA$, and the $\mathrm{Fe}-\mathrm{Co}$ site provides two anchoring sites for the dissociated $\mathrm{O}$ atoms. As a result, the dissociation barrier of $\mathrm{O}_{2}$ and $\mathrm{OOH}$ into $\mathrm{O}$ and $\mathrm{OH}$ is much lower than that of the corresponding single sites catalysts [73]. 
a

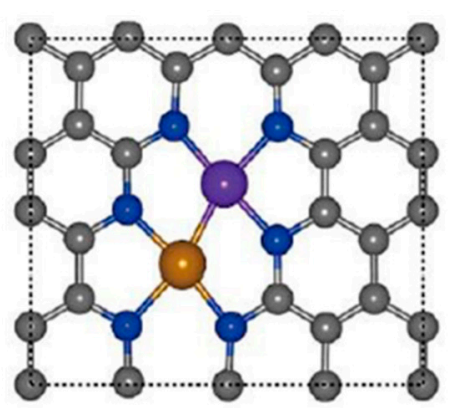

b

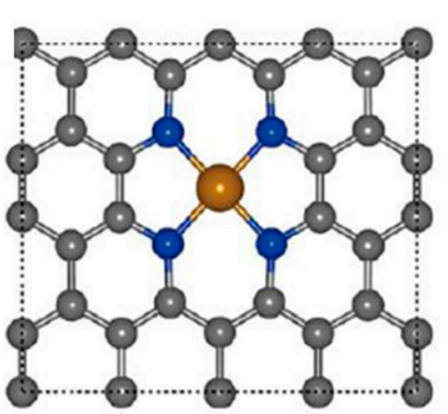

C

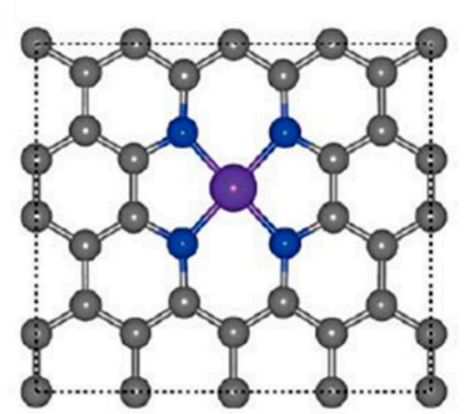

\section{$\odot \mathrm{C} \odot \mathrm{C} \odot \mathrm{Co} \odot$}

Figure 5. Structure comparison for dual-metal single-atom catalysts $(\mathrm{SAC})\left((\mathbf{a}) ;\left(\mathrm{Fe}, \mathrm{Co}-\mathrm{N}_{\mathrm{x}} / \mathrm{C}\right)\right)$ and mono-metal SACs ((b); $\left.\mathrm{Fe}-\mathrm{N}_{\mathrm{x}} / \mathrm{C} ; \mathbf{c}, \mathrm{Co}-\mathrm{N}_{\mathrm{x}} / \mathrm{C}\right)[73]$.

In addition to the capability to catalyze the ORR, $\mathrm{Fe}-\mathrm{N}_{\mathrm{x}} / \mathrm{C}$ can also catalyze the OER. It has been thought that $\mathrm{Fe}-\mathrm{Nx} / \mathrm{C}$ is a highly active catalyst for the ORR, while much less study has been conducted in the field of the OER. Recently, Chen at al. synthesized an Fe- $\mathrm{N}_{x}$ on a two-dimensional (2D) highly graphitic-porous, nitrogen-doped carbon layer $\left(\mathrm{FeN}_{\mathrm{x}}-\mathrm{PNC}\right)$. The $\mathrm{FeN}_{\mathrm{x}}-\mathrm{PNC}$ not only exhibits a good catalytic activity for the ORR but also shows exceptional OER performance with a low overpotential of $390 \mathrm{mV}$ at $10 \mathrm{~mA} \mathrm{~cm}^{-2}$. This character demonstrates the promising potential of $\mathrm{Fe}-\mathrm{N}_{\mathrm{x}} / \mathrm{C}$ for secondary rechargeable ZABs.

The common structure of $\mathrm{Fe}-\mathrm{N}_{\mathrm{x}} / \mathrm{C}$ is iron-nitrogen coordination dispersed on a conductive carbon support. Besides the rational design of the conductive structure, the bi-functional activity of the $\mathrm{Fe}-\mathrm{N}_{\mathrm{x}} / \mathrm{C}$-based SACs can also be effectively enhanced by introducing other heteroatoms ( $, \mathrm{P}, \mathrm{B}, \mathrm{O}$, etc.) into the carbon matrix (Figure 6) $[47,51,76]$. Besides nitrogen, the sulfur atom is probably the most widely used atom for doping strategies to enhance ORR/OER activity $[47,77]$. The presence of $S$ and $\mathrm{N}$ dopants can result in an uneven charge distribution in the carbon framework which further leads to positively charged carbon atoms, thus facilitating the adsorption of oxygen species [77]. When $B$ is used as a dopant atom in a carbon matrix, it can provide electron-deficient sites to improve the electron transfer for the $\mathrm{Fe}-\mathrm{N}_{\mathrm{x}}-\mathrm{C}$ sites and also strengthen the interaction with oxygen-containing species. A P dopant helps modify the electronic structure of Fe centers and weakens the adsorption of the ${ }^{*} \mathrm{OH}$ intermediate, which leads to improvement of the ORR. Meanwhile, the OER is also greatly enhanced [78].

In comparison with their mono-metal SACs counterparts, dual-metal $\mathrm{Fe}-\mathrm{N}_{\mathrm{x}} / \mathrm{C}$-based SACs may also have a better OER activity. A recent work related to dual-metal (Fe and Ni) SACs was conducted by Liu et al. In this work, they claimed that the electronic structures of SACs are reconfigured after the introduction of another metal. In the case of an Fe/Ni dual-metal SAC, the presence of Fe notably increases the oxidative state of the Ni site, which can lead to improved OER activity for the catalyst [79]. This study may provide promising guidance for the design of dual-metal SACs for the bi-functionally catalyzation of the ORR/OER. 
a

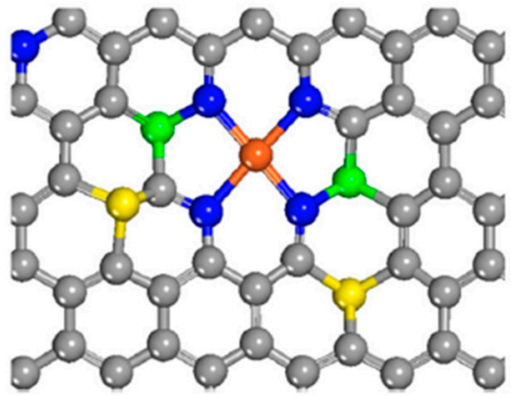

C

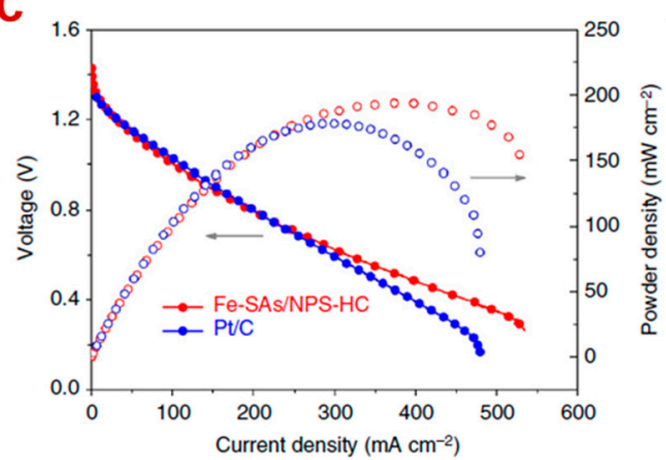

b

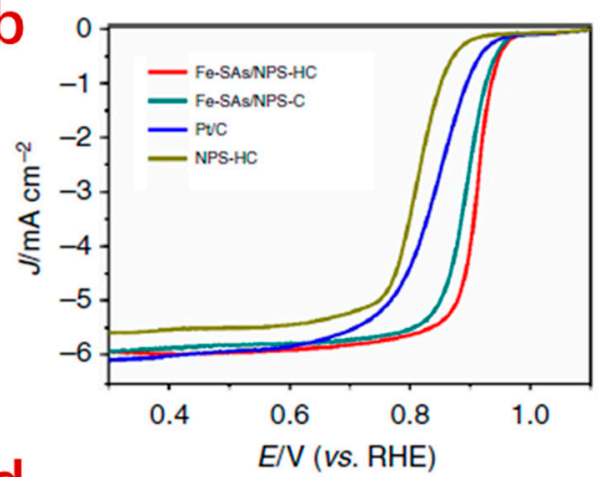

d

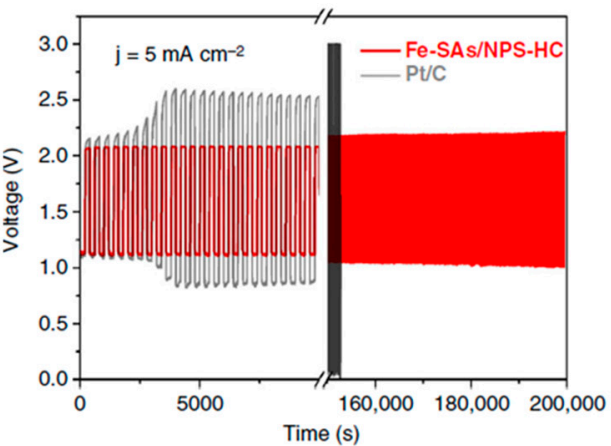

Figure 6. Structure of a ternary doped $\mathrm{Fe}-\mathrm{N}_{\mathrm{x}} / \mathrm{C}$ catalyst (Single iron atomic sites supported on a nitrogen, phosphorus and sulfur co-doped hollow carbon polyhedron (Fe-SAs/NPS)) (Fe (orange), $\mathrm{N}$ (blue), P (green), S (yellow) and C (gray)) (a), ORR performance comparison with single-doped and binary-doped analogues (b), and performance comparison for ZABs with these SACs and $\mathrm{Pt} / \mathrm{C}$ catalysts, respectively $(\mathbf{c}, \mathbf{d})[78]$.

\section{2. $\mathrm{Co}_{0}-\mathrm{N}_{x} / \mathrm{C}$-Based SACs}

\subsubsection{Mono-Metal Co- $\mathrm{N}_{\mathrm{x}} / \mathrm{C}$-Based SACs}

Apart from the $\mathrm{Fe}-\mathrm{N}_{\mathrm{x}} / \mathrm{C}$ catalysts, $\mathrm{Co}-\mathrm{N}_{\mathrm{x}} / \mathrm{C}$ is another widely investigated and effective catalyst for the ORR and the OER $[51,76,80]$. According to recent reports, despite its inferior ORR activity to $\mathrm{Fe}-\mathrm{N}_{\mathrm{x}} / \mathrm{C}, \mathrm{Co}-\mathrm{N}_{\mathrm{x}} / \mathrm{C}$ displays highly active performance in catalyzing both the ORR and the OER. $\mathrm{Co}-\mathrm{N}_{\mathrm{x}} / \mathrm{C}$ was widely investigated for the ORR before the concept of "single-atom catalysis" proposed by Zhang and co-workers [66]. The $\mathrm{Co}-\mathrm{N}_{\mathrm{x}}$ catalysis system can be traced back to a study by Jasinski in 1964 who firstly reported the nitrogen-metal coordination (cobalt phthalocyanine) catalytic structure [81], whereas the catalyst displayed very poor stability. To improve the performance, a further pyrolysis procedure in an inert atmosphere which can convert the metal-macrocyclic complex into metal- $\mathrm{N}_{\mathrm{x}}$ structure and effectively enhance the catalytic activity and stability for the ORR was employed [82]. From then on, extensive studies have been conducted on the development of various metal- $\mathrm{N}_{\mathrm{x}}$ electrocatalysts [83-87]. These catalysts may be regarded as the primary SAC systems despite the fact that the concept was not proposed until in 2011 [36]. Similar to $\mathrm{Fe}-\mathrm{N}_{\mathrm{x}} / \mathrm{C}$, mono-metal $\mathrm{Co}-\mathrm{N}_{\mathrm{x}} / \mathrm{C}$ can achieve a better performance than noble metal-based nanocatalysts in catalyzing the ORR/OER in alkaline aqueous-based ZABs $[88,89]$. A further improvement on the catalytic activity also requires increasing the active site number and promoting the intrinsic activity of each active site, strategies of which are similar to the aforementioned methods for $\mathrm{Fe}-\mathrm{N}_{\mathrm{x}} / \mathrm{C}$.

\subsubsection{Dual-Metal Co- $\mathrm{N}_{\mathrm{x}} / \mathrm{C}$-Based SACs}

For zinc-air batteries use, Zhao and co-workers designed a Zn-Co system coordinated on an $\mathrm{N}$-doped carbon matrix $(\mathrm{Zn} / \mathrm{CoN}-\mathrm{C})$ by a wet-chemical synthetic method. Both $\mathrm{Zn}$ and $\mathrm{Co}$ are coordinated $\mathrm{N}$ on a carbon matrix, and there is also a $\mathrm{Zn}-\mathrm{Co}$ bond in the system. Density functional 
Theory (DFT) calculations have shown that O-O (1.23 $\AA$ ) is slightly lengthened to 1.29 on $\mathrm{ZnN}_{4}$ and $1.30 \AA$ on $\mathrm{CoN}_{4}$, whereas it is greatly increased to $1.43 \AA$ on $\mathrm{Zn} / \mathrm{CoN}-\mathrm{C}$. It has been indicated that $\mathrm{ZnN}_{4}$ is less active than $\mathrm{CoN}_{4}$ and $\mathrm{Zn} / \mathrm{CoN}-\mathrm{C}$, while the coordination of dual-metal-atoms with nitrogen atoms is more favorable for the cleavage of $\mathrm{O}-\mathrm{O}$ bond. This has been further confirmed by the electrochemical measurement and zinc-air battery performance evaluation. An in situ X-ray absorption near edge structure (XANES) analysis was carried out to further investigate the $\mathrm{Zn} / \mathrm{CoN}-\mathrm{C}$ structure and reaction mechanism, which suggests that $\mathrm{Co}$ is actually the active center during the ORR. Meanwhile, it has been shown that $\mathrm{ZnN}-\mathrm{C}$ exhibits rather poor ORR electrocatalytic activity in an alkaline electrolyte (Figure 7). Therefore, it is reasonable to conclude that $\mathrm{Zn} / \mathrm{CoN}-\mathrm{C}$ can be regarded as a $\mathrm{Zn-enhanced} \mathrm{Co} \mathrm{single-atom} \mathrm{catalyst} \mathrm{rather} \mathrm{than} \mathrm{a} \mathrm{precise} \mathrm{single} \mathrm{atom} \mathrm{catalyst} \mathrm{in} \mathrm{terms}$ of structure and the electrochemical performance [74].

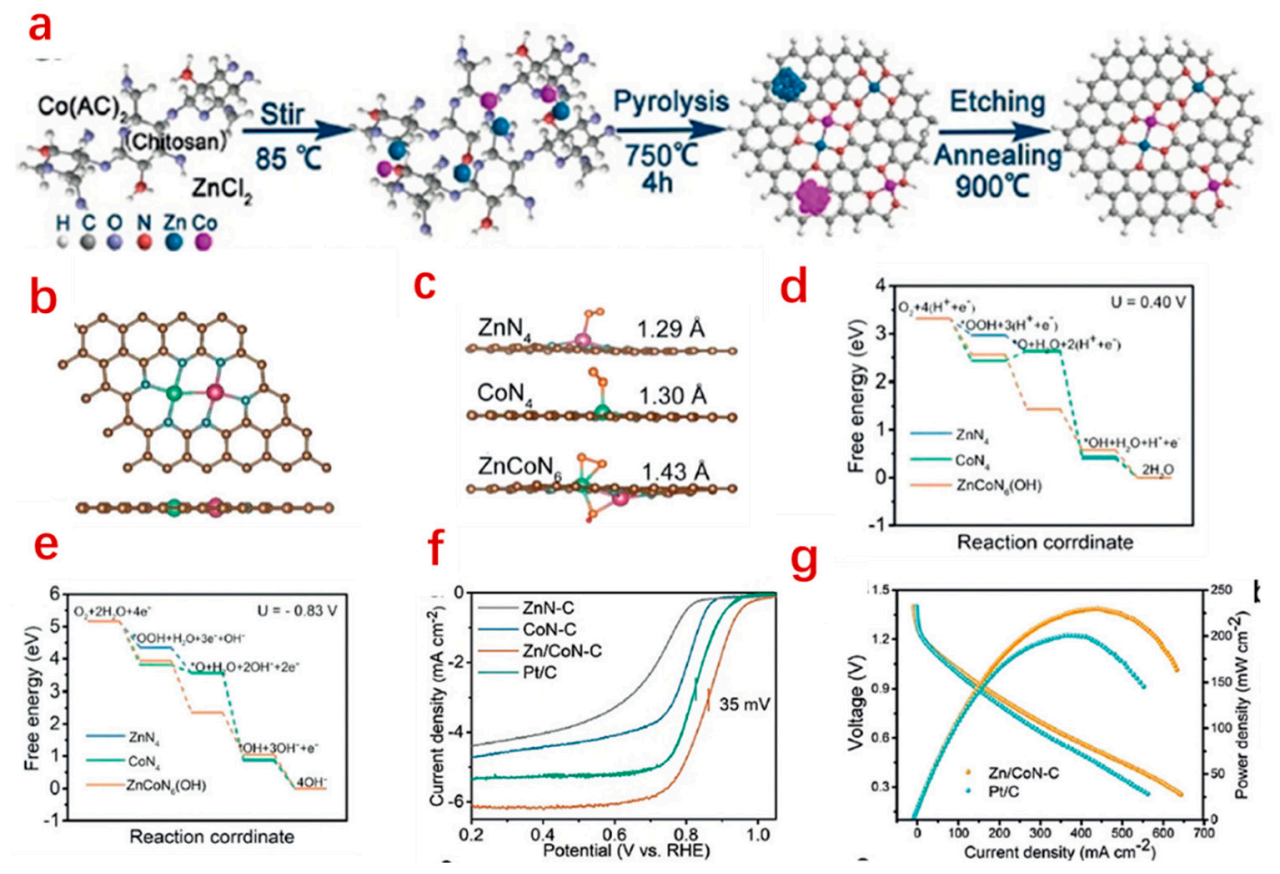

Figure 7. Schematic illustration of the synthesis process of $\mathrm{Zn} / \mathrm{CoN}-\mathrm{C}(\mathbf{a})$; the proposed structure of $\mathrm{Zn} / \mathrm{CoN}-\mathrm{C}$ (b); O-O bond length after adsorption on the various system (c); (brown, blue, yellow, green, purple, and red balls are $\mathrm{C}, \mathrm{N}, \mathrm{O}, \mathrm{Zn}, \mathrm{Co}$, and $\mathrm{H}$ atoms, respectively) free energy diagrams (d,e); ORR activity in an alkaline electrolyte (f); and zinc-air batteries performance (g) [74].

In addition, further doping the dual metal system with $\mathrm{S}$ atoms in the carbon layer can significantly enhance the intermediate adsorption and the electron transfer between the catalyst and the reaction intermediates generated in the ORR. The as-fabricated ZAB can deliver an improved power density [75].

\subsection{Other Metal-Based SACs}

Very recently, other transition metal- (such as $\mathrm{Cu}$ and $\mathrm{Mn}$ ) based SACs have been exploited and developed for catalyzing the ORR in ZABs $[54,55]$. It has been generally accepted that $\mathrm{Cu}$ is a poorly active metal for the ORR due to its filled d-electron shell. $\mathrm{Cu}$ has only one s-orbital electron on top of a filled d-electron shell $\left(3 \mathrm{~d}^{10} 4 \mathrm{~s}^{1}\right)$, which impedes the electron interactions with oxygen-containing intermediates such as ${ }^{*} \mathrm{OOH}$ and ${ }^{*} \mathrm{OH}$. This eventually weakens the oxygen chemisorption strength and thus leads to sluggish ORR kinetics [54,90]. However, when the size of $\mathrm{Cu}$ is reduced to the atomic scale and coordinated with the surrounding $\mathrm{N}$ atoms to form $\mathrm{CuN}_{2}$ or $\mathrm{CuN}_{4}$ (Figure 8a,b), the $\mathrm{d}$ electronic states are tuned to near the Fermi level; thus, the ORR catalytic activity is activated. This can be ascribed to the migration of the valence electrons from the $\mathrm{Cu}$ atoms to nitrogen. That is to say, atomically dispersing $\mathrm{Cu}$ can lead to a low coordination environment and an enhanced charge-transfer 
effect, which yields an increased number of active sites with enhanced intrinsic activity. Inspired by the catalytic activity of the ORR generated by the unsaturared $\mathrm{Cu}$ ion in $\mathrm{Cu}^{2+}$ enzymes, Yang et al. confirmed the isolated $\mathrm{Cu}$ single-atom catalyst exceeded $\mathrm{Pt} / \mathrm{C}$ in ORR and zinc-air battery operations. The atomically dispersed $\mathrm{Cu}-\mathrm{N}_{\mathrm{x}}$ are dominantly $\mathrm{Cu}-\mathrm{eN}$ with lesser amounts of $\mathrm{Cu}-\mathrm{N}_{2}$. Typically, the ORR occurs on the two moieties via different mechanisms. For example, the rate-determined step of the ORR on $\mathrm{Cu}-\mathrm{N}_{2}$ is ${ }^{*} \mathrm{OH}$ desorption, while that of ${ }^{*} \mathrm{OOH}$ is for $\mathrm{Cu}-\mathrm{N}_{4}$ (Figure $8 \mathrm{c}$ ). The calculated density of states (DOS) of $\mathrm{Cu}-\mathrm{N}_{2}$ and $\mathrm{Cu}-\mathrm{N}_{4}$ indicated that both of them exhibit an excess of $\mathrm{d}$ states near the Fermi level (Figure 8e,f), endowing the atomically dispersed $\mathrm{Cu}-\mathrm{N}_{\mathrm{x}}$ moiety with an appropriate interaction with oxygen-containing intermediates and a reduced barrier of ORR catalysis [54].

a

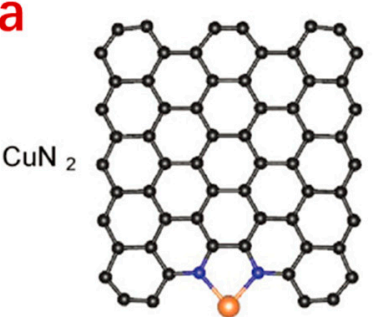

d

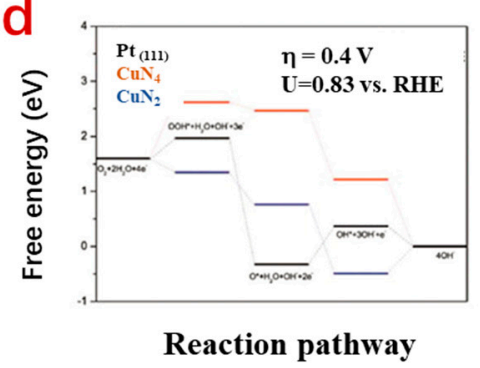

b

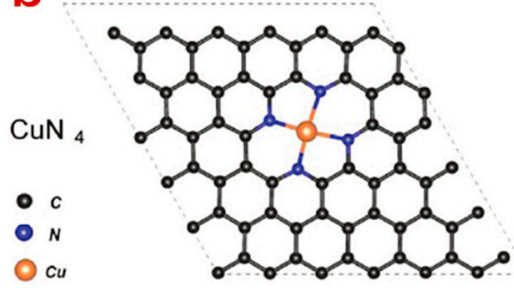

e

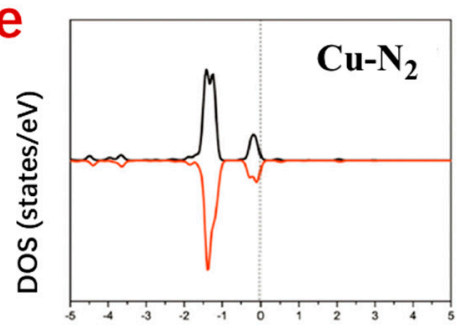

E- $\mathbf{E}_{\mathrm{F}}(\mathrm{eV})$

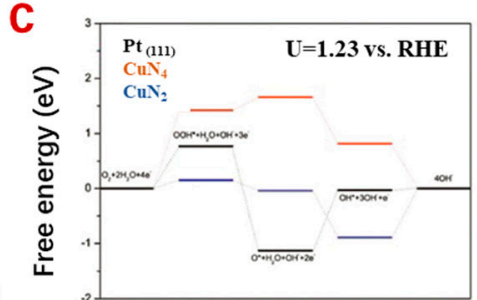

Reaction pathway

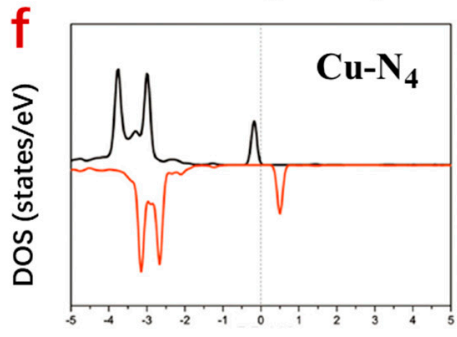

$\mathbf{E}-\mathbf{E}_{\mathrm{F}}(\mathrm{eV})$

Figure 8. Optimized structures of $\mathrm{Cu}-\mathrm{N}_{2}(\mathbf{a})$ and $\mathrm{Cu}-\mathrm{N}_{4}(\mathbf{b})$; ORR free energy diagrams of $\mathrm{CuN}_{2}$ and $\mathrm{CuN}_{4}(\mathbf{c}, \mathbf{d})$ at different potentials; local density of states (LDOS) of the d-orbitals of $\mathrm{Cu}$ atoms in $\mathrm{Cu}-\mathrm{N}_{2}$

(e) and $\mathrm{Cu}-\mathrm{N}_{4}(\mathbf{f})[54]$.

In contrast to the incomplete d-shells of $\mathrm{Fe}\left(3 \mathrm{~d}^{6} 4 \mathrm{~s}^{2}\right)$ and $\mathrm{Co}\left(3 \mathrm{~d}^{6} 4 \mathrm{~s}^{2}\right)$, Mn has a half-filled d-electron shell $\left(3 \mathrm{~d}^{5} 4 \mathrm{~s}^{2}\right)$ stable structure which is considered as an inferior active metal to Co and Fe. However, by downsizing $\mathrm{Mn}$ onto the atomic scale and tuning the surrounding coordination environment, $\mathrm{Mn}$ can be activated to catalyze the ORR due to its d-electrons being tuned to a rational state [33,55]. This may provide valuable and promising guidance to exploit more low-cost and relevant inert metal resources for the active SACs system.

In average, based on current reports, the catalytic activity of diverse SACs in ZAB catalysis primarily follows the order: $\mathrm{Fe}-\mathrm{N}_{\mathrm{x}}>\mathrm{Co}-\mathrm{N}_{\mathrm{x}}>\mathrm{Cu}-\mathrm{N}_{\mathrm{x}}>\mathrm{Mn}-\mathrm{N}_{\mathrm{x}}$. To illustrate the recent advances of SACs in ZABs, Table 1 summarizes the specific activities according to the recent reports.

Table 1. Performance of ZABs using the recent representative SACs.

\begin{tabular}{|c|c|c|c|}
\hline Catalyst & Active Material & ZABs Performance & Ref \\
\hline Fe-SAs/N-C & $\begin{array}{l}\mathrm{FeN}_{4} \text { embedded in an N-doped } \\
\text { carbon matrix. }\end{array}$ & $\begin{array}{l}\text { The maximum power density is } 225 \mathrm{~mW} \\
\mathrm{~cm}^{-2} \text {. The specific capacity is } \sim 636 \mathrm{mAh} \\
\mathrm{g}^{-1} .260 \text { h operation without significant } \\
\text { discharge voltage loss. }\end{array}$ & [67] \\
\hline $\mathrm{Fe}-\mathrm{NCCs}$ & $\begin{array}{l}\text { Atomic } \mathrm{Fe}-\mathrm{N}_{\mathrm{x}} \text { dispersed in a } \\
\text { carbon matrix. }\end{array}$ & $\begin{array}{l}\text { The maximum power density is } 66 \mathrm{~mW} \\
\mathrm{~cm}^{-2} \text {. The specific capacity of } 705 \mathrm{mAh} \mathrm{g}^{-1} \\
\text { at } 5 \mathrm{~mA} \mathrm{~cm}{ }^{-2} \text { and a negligible voltage loss } \\
\text { after continuous operation for } 67 \mathrm{~h} \text {. }\end{array}$ & [53] \\
\hline
\end{tabular}


Table 1. Cont

\begin{tabular}{|c|c|c|c|}
\hline Catalyst & Active Material & ZABs Performance & Ref \\
\hline $\mathrm{SA}-\mathrm{Fe} / \mathrm{NG}$ & $\begin{array}{l}\text { Fe-pyrrolic-N species ON } \\
\text { N-doped graphitic carbon. }\end{array}$ & $\begin{array}{l}\text { The maximum power density is } \\
91 \mathrm{~mW} \mathrm{~cm}^{-2} \text {. A negligible voltage loss } \\
\text { after continuous operation for } 20 \mathrm{~h} \text {. }\end{array}$ & [91] \\
\hline Fe-SAs/NPS-HC & $\begin{array}{l}\text { Single iron atomic sites } \\
\text { supported on a nitrogen, } \\
\text { phosphorus and sulfur co-doped } \\
\text { hollow carbon polyhedron. }\end{array}$ & $\begin{array}{l}\text { The maximum power density is } \\
195 \mathrm{~mW} \mathrm{~cm}{ }^{-2} \text {. A negligible voltage loss } \\
\text { after continuous operation for } 55.6 \mathrm{~h} \text {. }\end{array}$ & [78] \\
\hline Fe-SAs/MC & $\begin{array}{l}\text { FeN }_{x} \text { moiety supported on } \\
\text { N-doped mesoporous carbon. }\end{array}$ & $\begin{array}{c}\text { The specific capacity is } \sim 739 \mathrm{mAh} \mathrm{g}^{-1} \text { at a } \\
\text { discharge current density of } 5 \mathrm{~mA} \mathrm{~cm}^{-2} \text {. } \\
\text { A negligible voltage loss after continuous } \\
\text { operation for } 3 \text { cycles. }\end{array}$ & [92] \\
\hline $\mathrm{Fe}-\mathrm{N}-\mathrm{SCCFs}$ & $\begin{array}{l}\text { Fe, N-codoped, graphitic } \\
\text { simple-cubic carbon } \\
\text { frameworks. }\end{array}$ & $\begin{array}{l}\text { The maximum power density is } \\
297 \mathrm{~mW} \mathrm{~cm}^{-2} \text {. A negligible voltage loss } \\
\text { after continuous operation for after } 16 \mathrm{~h} \text { at } \\
10 \mathrm{~mA} \mathrm{~cm}^{-2} \text { and } 10 \mathrm{~h} \text { at } 50 \mathrm{~mA} \mathrm{~cm}^{-2} \text {. }\end{array}$ & [93] \\
\hline $\mathrm{A}-\mathrm{Co} / \mathrm{r}-\mathrm{GO}$ & $\begin{array}{l}\text { Atomically-dispersed Co on } \\
\text { reduced graphene oxide. }\end{array}$ & $\begin{array}{l}\text { The maximum power density is } \\
225 \mathrm{~mW} \mathrm{~cm}^{-2} \text {. The specific capacity of } \\
795 \mathrm{mAh} \mathrm{g}^{-1} \text { and a negligible voltage loss } \\
\text { after continuous operation for } 50 \mathrm{~h} \text {. }\end{array}$ & [94] \\
\hline $\mathrm{Zn} / \mathrm{CoN}-\mathrm{C}$ & $\begin{array}{l}\text { Zn and Co dual metals atoms } \\
\text { coordinated by } \mathrm{N} \text { on a carbon } \\
\text { support. }\end{array}$ & $\begin{array}{l}\text { The maximum power density is } \\
230 \mathrm{~mW} \mathrm{~cm} \mathrm{~m}^{-2} \text {. A negligible voltage loss } \\
\text { after continuous operation for } 28 \mathrm{~h} \text { at } \\
5 \mathrm{~mA} \mathrm{~cm}^{-2} \text {. }\end{array}$ & [74] \\
\hline $\mathrm{Zn}, \mathrm{Co}-\mathrm{N}_{\mathrm{x}}-\mathrm{C}-\mathrm{Sy}$ & $\begin{array}{l}\text { Sulfur (S)-modified } \mathrm{Zn} \text { and } \\
\text { Co- } \mathrm{N}_{\mathrm{x}}-\mathrm{C}-\text { Sy bimetallic sites } \\
\text { embedded in dendritic carbon. }\end{array}$ & $\begin{array}{l}\text { The maximum power density is } \\
150 \mathrm{~mW} \mathrm{~cm}^{-2} \text {. A negligible voltage loss } \\
\text { after continuous operation for } 22 \mathrm{~h} \text { at } \\
\quad 5 \mathrm{~mA} \mathrm{~cm}^{-2} \text {. }\end{array}$ & [75] \\
\hline $\mathrm{Mn} / \mathrm{C}-\mathrm{NO}$ & $\begin{array}{l}\mathrm{O} \text { and } \mathrm{N} \text { atoms coordinated } \mathrm{Mn} \\
\text { active sites incorporated within } \\
\text { graphene frameworks. }\end{array}$ & $\begin{array}{l}120 \mathrm{~mW} \mathrm{~cm}^{-2} \text { at } 0.7 \mathrm{~V} \text { The maximun power } \\
\text { density is } 120 \mathrm{~mW} \mathrm{~cm} \mathrm{~m}^{-2} \text {. A negligible } \\
\text { voltage loss after continuous operation for } \\
5.6 \mathrm{~h} \text { at } 20 \mathrm{~mA} \mathrm{~cm} \mathrm{~m}^{-2} \text {. }\end{array}$ & [55] \\
\hline S-600 & $\begin{array}{l}\text { Atomically dispersed } \mathrm{Cu}-\mathrm{N}_{\mathrm{x}} \\
\text { moiety in a 3D graphene } \\
\text { framework. }\end{array}$ & $\begin{array}{l}\text { The maximum power density is } \\
160 \mathrm{~mW} \mathrm{~cm}-2 \text {. A negligible voltage loss } \\
\text { after continuous operation for } 10 \mathrm{~h} \text { at } \\
20 \mathrm{~mA} \mathrm{~cm}^{-2} \text {. }\end{array}$ & [54] \\
\hline $\mathrm{FeN}_{\mathrm{x}}-\mathrm{PNC}$ & $\begin{array}{l}\mathrm{FeN}_{\mathrm{x}} \text { moiety on a } 2 \mathrm{D} \text { porous } \\
\mathrm{N} \text {-doped carbon layer. }\end{array}$ & $\begin{array}{l}\text { The maximum power density is } \\
278 \mathrm{~mW} \mathrm{~cm} \mathrm{~m}^{-2} \text {. A negligible voltage loss } \\
\text { after continuous operation for } 40 \mathrm{~h} \text { at } \\
\quad 5 \mathrm{~mA} \mathrm{~cm}^{-2} \text {. }\end{array}$ & [49] \\
\hline FeNPC & $\begin{array}{l}\mathrm{N} \text { and } \mathrm{P} \text { co-coordinated } \mathrm{Fe} \\
\text { atoms in carbon hollow spheres. }\end{array}$ & $\begin{array}{l}233.2 \mathrm{~mW} \mathrm{~cm}^{-2} \text { at } 0.79 \mathrm{~V} \text { The maximun } \\
\text { power density is } 233.2 \mathrm{~mW} \mathrm{~cm}^{-2} \text {. } \\
\text { A negligible voltage loss after continuous } \\
\text { charge/discharge for } 15 \mathrm{~h} \text { at } 3 \mathrm{~mA} \mathrm{~cm}^{-2} \text {. }\end{array}$ & [95] \\
\hline Meso/micro-Fe- $\mathrm{N}_{\mathrm{x}}-\mathrm{CN}-30$ & $\begin{array}{c}\text { Meso/microporous } \\
\text { FeCo- } \mathrm{N}_{\mathrm{x}} \text {-carbon nanosheets. }\end{array}$ & $\begin{array}{l}\text { The maximum power density is } \\
150 \mathrm{~mW} \mathrm{~cm} \text {. A negligible voltage loss } \\
\text { after continuous charge/discharge for } 28 \mathrm{~h} \\
\text { at } 5 \mathrm{~mA} \mathrm{~cm}-2 \text {. }\end{array}$ & [96] \\
\hline $\mathrm{S}, \mathrm{N}-\mathrm{Fe} / \mathrm{N} / \mathrm{C}-\mathrm{CNT}$ & $\begin{array}{l}\text { Atomically dispersed } \mathrm{Fe}-\mathrm{N}_{\mathrm{x}} \text { on } \\
\mathrm{N} \text { and } \mathrm{S} \text { co-doped hierarchical } \\
\text { carbon layers. }\end{array}$ & $\begin{array}{c}\text { The maximum power density is } \\
102.7 \mathrm{~mW} \mathrm{~cm}^{-2} \text {. A negligible voltage loss } \\
\text { after continuous charge/discharge for over } \\
100 \text { cycles. }\end{array}$ & [77] \\
\hline NGM-Co & $\begin{array}{c}\mathrm{Co} / \mathrm{N} / \mathrm{O} \text { tri-doped graphene } \\
\text { mesh. }\end{array}$ & $\begin{array}{l}\text { The maximum power density is } \\
152 \mathrm{~mW} \mathrm{~cm}^{-2} \text {. The specific capacity at } \\
20.0 \mathrm{~mA} \mathrm{~cm}^{-2} \text { is } \sim 750 \mathrm{mAh}^{-1} \text {. } \\
\text { A negligible voltage loss after continuous } \\
\text { charge/discharge for } 60 \mathrm{~h} \text { at } 2 \mathrm{~mA} \mathrm{~cm}^{-2} \text {. }\end{array}$ & [57] \\
\hline
\end{tabular}


Table 1. Cont

\begin{tabular}{|c|c|c|c|}
\hline Catalyst & Active Material & ZABs Performance & Ref \\
\hline Fe-NSDC & $\begin{array}{l}\mathrm{N} \text { and } \mathrm{S} \text { co-doped } \mathrm{Fe}-\mathrm{N}-\mathrm{C} \\
\text { species. }\end{array}$ & $\begin{array}{l}\text { The maximum power density is } \\
225.1 \mathrm{~mW} \mathrm{~cm}^{-2} \text {. The specific capacity at } \\
4 \mathrm{~mA} \mathrm{~cm}^{-2} \text { is } \sim 740.8 \mathrm{mAh}^{-1} \text {. A long } \\
\text { deep cycle life over the last } 100 \text { cycles with } \\
\text { the charge-discharge overpotential } \\
\text { changed from } 0.70 \mathrm{~V} \text { at the } 300 \text { th cycle to } \\
0.71 \mathrm{~V} \text { at the } 400 \text { th cycle, corresponding to } \\
1.4 \% \text { decrease of voltaic efficiency. }\end{array}$ & [47] \\
\hline $\mathrm{Fe}-\mathrm{Nx}-\mathrm{C}$ & $\begin{array}{l}\text { Isolated single-atom iron on } \\
\mathrm{N} \text {-doped carbon frameworks. }\end{array}$ & $\begin{array}{c}\text { The maximum power density is } \\
96.4 \mathrm{~mW} \mathrm{~cm}^{-2} \text {. The specific capacity is } \\
641 \mathrm{mAh} \mathrm{g}^{-1} \text {. A negligible voltage loss } \\
\text { after continuous charge/discharge for } 33.3 \mathrm{~h} \\
\text { at } 10 \mathrm{~mA} \mathrm{~cm}{ }^{-2} \text {. }\end{array}$ & [97] \\
\hline Co-N, B-CSs & $\begin{array}{l}\text { Boron (B)-doped } \mathrm{Co}-\mathrm{N}-\mathrm{C} \text { active } \\
\text { sites confined in hierarchical } \\
\text { porous carbon sheets. }\end{array}$ & $\begin{array}{l}\text { The maximum power density is } \\
100.4 \mathrm{~mW} \mathrm{~cm}^{-2} \text {. The specific capacity is } \\
641 \mathrm{mAh} \mathrm{g}^{-1} \text {. A negligible voltage loss } \\
\text { after continuous charge/discharge for } 14 \mathrm{~h} \\
\text { at } 5 \mathrm{~mA} \mathrm{~cm}{ }^{-2} \text {. }\end{array}$ & [51] \\
\hline NC-Co-SA & $\begin{array}{l}\text { Co- } \mathrm{N}_{\mathrm{X}} \text { sites in } \mathrm{N} \text {-doped porous } \\
\text { carbon nanoflake arrays. }\end{array}$ & $\begin{array}{l}\text { The maximum power density of the } \\
\text { all-solid-state ZAB is } 20 \mathrm{~mW} \mathrm{~cm}^{-2} \text {. } \\
\text { The all-solid state battery showed very } \\
\text { stable upon charge/discharge for } 2500 \mathrm{~min} \\
\text { (125 cycles) in its flat state and } 2200 \mathrm{~min} \\
\text { (110 cycles) in its bent state. }\end{array}$ & [80] \\
\hline $\mathrm{CoN} 4 / \mathrm{NG}$ & $\begin{array}{l}\mathrm{CoN}_{4} \text { moiety dispersed on } \\
\mathrm{N} \text {-doped graphitic nanosheet. }\end{array}$ & $\begin{array}{c}\text { The maximum power density is } \\
115 \mathrm{~mW} \mathrm{~cm}^{-2} \text {. The specific capacity is } \\
730 \mathrm{mAh} \mathrm{g}^{-1} \text {. A negligible voltage loss } \\
\text { after continuous charge/discharge for } 100 \mathrm{~h} \\
\text { at } 10 \mathrm{~mA} \mathrm{~cm}{ }^{-2} \text {. }\end{array}$ & [98] \\
\hline EA-Co-900 & $\begin{array}{l}\text { Isolated Co single atoms } \\
\text { anchored on N-doped hollow } \\
\text { carbon tube. }\end{array}$ & $\begin{array}{l}\text { The maximum power density is } \\
73 \mathrm{~mW} \mathrm{~cm}{ }^{-2} \text {. A negligible voltage loss } \\
\text { after continuous charge/discharge for } 100 \mathrm{~h} \\
\text { at } 20 \mathrm{~mA} \mathrm{~cm}^{-2} \text {. }\end{array}$ & [99] \\
\hline Co SA@NCF/CNF & $\begin{array}{l}\text { Single Co atoms anchored } \\
\text { N-doped carbon flake arrays } \\
\text { grown on carbon nanofibers. }\end{array}$ & $\begin{array}{c}\text { The specific capacity is } 530.17 \mathrm{mAh}^{-1} \text {. A } \\
\text { negligible voltage loss after continuous } \\
\text { charge/discharge for } 90 \text { cycles. }\end{array}$ & [100] \\
\hline SCoNC & $\begin{array}{c}\text { Monodispersed Co single atoms } \\
\text { on a N-doped 2D carbon } \\
\text { nanosheets }\end{array}$ & $\begin{array}{c}\text { The maximum power density is } \\
194 \mathrm{~mW} \mathrm{~cm}^{-2} \text {. The specific capacity is } \\
690 \mathrm{mAh} \mathrm{g}^{-1} \text { at } 10 \mathrm{~mA} \mathrm{~cm}^{-2} \text {. A negligible } \\
\text { voltage loss after continuous } \\
\text { charge/discharge for } 20 \mathrm{~h} \text { at } 5 \mathrm{~mA} \mathrm{~cm}{ }^{-2} \text {. }\end{array}$ & [88] \\
\hline
\end{tabular}

\section{Summary and Prospect}

In summary, SACs have been introduced in the ZABs field as unique and new frontier catalysts. Due to their maximum atom-utilization efficiency, fully exposed active sites, and the increased ratio of undercoordinated atoms, SACs show exceptional catalytic activity and selectivity in ZABs. This gives SACs great potential as alternatives to noble metal catalysts in ZABs. Among the diverse SACs, Co- and Fe-SACs perform best for the ORR, while more kinds of metal that used to be considered less active catalysts have been exploited as active SAC catalysts for ZABs. Therefore, it is also worth exploring more metal resources for SAC catalysts in ZABs.

However, the single atomization of metal atoms alone is not sufficient to efficiently catalyze the ORR/OER in ZABs and achieve a high power density. To satisfactorily catalyze the reactions in ZABs, a sufficient number of active sites and a high intrinsic activity of the active sites are extremely critical for the catalysts. In addition, even in the same $\mathrm{MN}_{\mathrm{x}}$ moiety-based SACs, the catalytic activity may be quite different. This can be ascribed to the different atom loading densities on the carbon support and the different intrinsic activity of the isolated active sites. Obviously, the two factors are greatly 
influence by synthetic methodologies. Furthermore, the density of single-atom sites may change the mechanism for electrochemical reactions. For example, high density single-atom sites may facilitate the formation of adjacent active sites which benefit from the cleavage of the $\mathrm{O}-\mathrm{O}$ bond and results in a four-electron pathway for the ORR. Therefore, it is extremely critical to take appropriate synthetical strategies to fabricate satisfying single-atom catalysts. To fabricate efficient SACs for zinc-air batteries, the following points may be considered.

(1) Selecting a desired metal-based complex which can be converted to isolated single-atom sites helps achieve a high loading single-atom catalyst. Due to the high surface energy of the isolated atoms, most the current single-atom catalysts maintain very low loading on the support against the migration and agglomeration upon synthesis and application. Because the surface energy sharply increases when the particle size is decreased from the nano scale to atomic scale, low temperature pyrolysis can avoid the agglomeration of metal atoms upon synthesis.

(2) A complex with abundant coordination sites and various hard or soft templates may be an optimized precursor to obtain a high loading of single atoms on the support and provide a high electrochemical active surface area for the catalysts to react. The coordination between the active single atom and the coordination sites exerts a space isolation effect against the agglomeration during high temperature annealing. The high electrochemical active surface area can endow the catalyst with an excellent accessibility to reactions, which facilitates the process of electrochemical reaction.

(3) Binding the active single atom with a foreign atom could be an effective strategy to enhance the catalytic activity of single-atom catalyst. The enhancing active sites tend to lengthen $\mathrm{O}-\mathrm{O}$ bond lengths, which facilitate the cleavage of $\mathrm{O}-\mathrm{O}$ bonds and thus achieves a four-electron pathway. Inspired by the previous results, incorporating noble metal atoms such as $\mathrm{Pt}$, $\mathrm{Pd}$, or Au with a noble metal atom may be an effective way to alter their two-electron mechanism into a four-electron mechanism for the ORR. This may extend the application of the cost-effective noble SACs into energy conversion systems such ZABs and fuel cells.

Overall, due to their unique structure and unsaturated properties, SACs have demonstrated their excellent catalytic activity and a promising potential for catalyzing various electrochemical reactions. Additionally, it is believed that their high performance can promote ZABs as a competitive energy conversion system in comparison with other commercial energy devices.

Author Contributions: W.Z. and Y.L. mainly draft this review. L.Z. and J.C. provide the conceptualization and edit the final draft.

Funding: This research was funded by National Natural Science Foundation of China (21776175), and Australian Research Council (CE140100012). The authors thank the Australian National Fabrication Facility (ANFF)-Materials Node.

Conflicts of Interest: The authors declare no conflict of interest.

\section{References}

1. Liu, D.; Tong, Y.; Yan, X.; Liang, J.; Dou, S.X. Recent advances in carbon-based bifunctional oxygen catalysts for Zinc-air batteries. Batter. Supercaps 2019, 2, 743-765. [CrossRef]

2. Fu, J.; Cano, Z.P.; Park, M.G.; Yu, A.; Fowler, M.; Chen, Z. Electrically rechargeable Zinc-air batteries: Progress, challenges, and perspectives. Adv. Mater. 2017, 29, 1604685. [CrossRef] [PubMed]

3. Zhang, T.; Tao, Z.; Chen, J. Magnesium-air batteries: From principle to application. Mater. Horiz. 2014, 1, 196-206. [CrossRef]

4. Lee, J.-S.; Tai Kim, S.; Cao, R.; Choi, N.-S.; Liu, M.; Lee, K.T.; Cho, J. Metal-air batteries with high energy density: Li-air versus $\mathrm{Zn-air.} \mathrm{Adv.} \mathrm{Energy} \mathrm{Mater.} \mathrm{2011,} \mathrm{1,} \mathrm{34-50.} \mathrm{[CrossRef]}$

5. Li, Y.; Lu, J. Metal-air batteries: Will they be the future electrochemical energy storage device of choice? ACS Energy Lett. 2017, 2, 1370-1377. [CrossRef]

6. Luntz, A.C.; McCloskey, B.D. Nonaqueous Li-air batteries: A status report. Chem. Rev. 2014, 114, 11721-11750. [CrossRef] 
7. McKerracher, R.D.; Ponce de Leon, C.; Wills, R.G.A.; Shah, A.A.; Walsh, F.C. A review of the Iron-air secondary battery for energy storage. ChemPlusChem 2015, 80, 323-335. [CrossRef]

8. Li, Y.; Dai, H. Recent advances in Zinc-air batteries. Chem. Soc. Rev. 2014, 43, 5257-5275. [CrossRef]

9. Cong, G.; Wang, W.; Lai, N.-C.; Liang, Z.; Lu, Y.-C. A high-rate and long-life organic-oxygen battery. Nat. Mater. 2019, 18, 390-396. [CrossRef]

10. Pan, J.; Xu, Y.Y.; Yang, H.; Dong, Z.; Liu, H.; Xia, B.Y. Advanced architectures and relatives of air electrodes in Zn-air batteries. Adv. Sci. 2018, 5, 1700691. [CrossRef]

11. Weinrich, H.; Durmus, Y.E.; Tempel, H.; Kungl, H.; Eichel, R.-A. Silicon and iron as resource-efficient anode materials for ambient-temperature Metal-air batteries: A review. Materials 2019, 12, 2134. [CrossRef] [PubMed]

12. Mainar, A.R.; Iruin, E.; Colmenares, L.C.; Kvasha, A.; de Meatza, I.; Bengoechea, M.; Leonet, O.; Boyano, I.; Zhang, Z.; Blazquez, J.A. An overview of progress in electrolytes for secondary Zinc-air batteries and other storage systems based on Zinc. J. Energy Storage 2018, 15, 304-328. [CrossRef]

13. Xu, M.; Ivey, D.G.; Xie, Z.; Qu, W. Rechargeable Zn-air batteries: Progress in electrolyte development and cell configuration advancement. J. Power Sources 2015, 283, 358-371. [CrossRef]

14. Lu, Y.-C.; Xu, Z.; Gasteiger, H.A.; Chen, S.; Hamad-Schifferli, K.; Shao-Horn, Y. Platinum-Gold nanoparticles: A highly active bifunctional electrocatalyst for rechargeable Lithium-air batteries. J. Am. Chem. Soc. 2010, 132, 12170-12171. [CrossRef]

15. Wang, T.; Kaempgen, M.; Nopphawan, P.; Wee, G.; Mhaisalkar, S.; Srinivasan, M. Silver nanoparticle-decorated carbon nanotubes as bifunctional gas-diffusion electrodes for Zinc-air batteries. J. Power Sources 2010, 195, 4350-4355. [CrossRef]

16. Jin, Y.; Chen, F. Facile preparation of Ag-Cu bifunctional electrocatalysts for Zinc-air batteries. Electrochim. Acta 2015, 158, 437-445. [CrossRef]

17. Liang, H.-W.; Wu, Z.-Y.; Chen, L.-F.; Li, C.; Yu, S.-H. Bacterial cellulose derived nitrogen-doped carbon nanofiber aerogel: An efficient metal-free oxygen reduction electrocatalyst for Zinc-air battery. Nano Energy 2015, 11, 366-376. [CrossRef]

18. Cai, X.; Xia, B.Y.; Franklin, J.; Li, B.; Wang, X.; Wang, Z.; Chen, L.; Lin, J.; Lai, L.; Shen, Z. Free-standing vertically-aligned nitrogen-doped carbon nanotube arrays/graphene as air-breathing electrodes for rechargeable Zinc-air batteries. J. Mater. Chem. A 2017, 5, 2488-2495. [CrossRef]

19. Wang, L.; Wang, Y.; Wu, M.; Wei, Z.; Cui, C.; Mao, M.; Zhang, J.; Han, X.; Liu, Q.; Ma, J. Nitrogen, Fluorine, and Boron ternary doped carbon fibers as cathode electrocatalysts for Zinc-air batteries. Small 2018, 14, 1800737. [CrossRef]

20. Khan, Z.; Park, S.O.; Yang, J.; Park, S.; Shanker, R.; Song, H.-K.; Kim, Y.; Kwak, S.K.; Ko, H. Binary N,S-doped carbon nanospheres from bio-inspired artificial melanosomes: A route to efficient air electrodes for seawater batteries. J. Mater. Chem. A 2018, 6, 24459-24467. [CrossRef]

21. Liu, X.; Wang, L.; Yu, P.; Tian, C.; Sun, F.; Ma, J.; Li, W.; Fu, H. A stable bifunctional catalyst for rechargeable Zinc-air batteries: Iron-Cobalt nanoparticles embedded in a Nitrogen-doped 3D Carbon matrix. Angew. Chem. Int. Ed. 2018, 57, 16166-16170. [CrossRef]

22. Liu, X.; Park, M.; Kim, M.G.; Gupta, S.; Wu, G.; Cho, J. Integrating NiCo alloys with their oxides as efficient bifunctional cathode catalysts for rechargeable Zinc-air batteries. Angew. Chem. Int. Ed. 2015, 54, 9654-9658. [CrossRef]

23. Ma, T.Y.; Cao, J.L.; Jaroniec, M.; Qiao, S.Z. Interacting carbon nitride and titanium carbide nanosheets for high-performance oxygen evolution. Angew. Chem. Int. Ed. 2016, 55, 1138-1142. [CrossRef] [PubMed]

24. Wang, Q.; Xue, Y.; Sun, S.; Li, S.; Miao, H.; Liu, Z. La0.8Sr0.2Co1-xMnxO3 perovskites as efficient bi-functional cathode catalysts for rechargeable Zinc-air batteries. Electrochim. Acta 2017, 254, 14-24. [CrossRef]

25. Bu, L.; Zhang, N.; Guo, S.; Zhang, X.; Li, J.; Yao, J.; Wu, T.; Lu, G.; Ma, J.-Y.; Su, D.; et al. Biaxially strained $\mathrm{PtPb} / \mathrm{Pt}$ core/shell nanoplate boosts oxygen reduction catalysis. Science 2016, 354, 1410-1414. [CrossRef]

26. Jiang, K.; Zhao, D.; Guo, S.; Zhang, X.; Zhu, X.; Guo, J.; Lu, G.; Huang, X. Efficient oxygen reduction catalysis by subnanometer Pt alloy nanowires. Sci. Adv. 2017, 3, e1601705. [CrossRef] [PubMed]

27. Cao, R.; Lee, J.-S.; Liu, M.; Cho, J. Recent progress in non-precious catalysts for Metal-air batteries. Adv. Energy Mater. 2012, 2, 816-829. [CrossRef]

28. Rossmeisl, J.; Qu, Z.W.; Zhu, H.; Kroes, G.J.; Nørskov, J.K. Electrolysis of water on oxide surfaces. J. Electroanal. Chem. 2007, 607, 83-89. [CrossRef] 
29. Troyanchuk, I.O.; Trukhanov, S.V.; Khalyavin, D.D.; Szymczak, H. Magnetic properties of anion deficit manganites $\operatorname{Ln}_{0.55} \mathrm{Ba}_{0.45} \mathrm{MnO}_{3-\gamma}(\mathrm{Ln}=\mathrm{La}, \mathrm{Nd}, \mathrm{Sm}, \mathrm{Gd}, \gamma \leqslant 0.37)$. J. Magn. Magn. Mater. 2000, 208, 217-220. [CrossRef]

30. Hou, N.; Yao, T.; Li, P.; Yao, X.; Gan, T.; Fan, L.; Wang, J.; Zhi, X.; Zhao, Y.; Li, Y. A-site ordered double perovskite with in situ exsolved core-shell nanoparticles as anode for solid oxide fuel cells. ACS Appl. Mater. Interfaces 2019, 11, 6995-7005. [CrossRef]

31. Trukhanov, S.; Lobanovsky, L.; Bushinsky, M.; Fedotova, V.; Troyanchuk, I.; Trukhanov, A.; Ryzhov, V.; Szymczak, H.; Szymczak, R.; Baran, M. Study of a-site ordered PrBaMn2O6- $\delta$ manganite properties depending on the treatment conditions. J. Phys. Condens. Matter 2005, 17, 6495-6506. [CrossRef]

32. Antipov, E.V.; Abakumov, A.M.; Istomin, S.Y. Target-aimed synthesis of anion-deficient perovskites. Inorg. Chem. 2008, 47, 8543-8552. [CrossRef] [PubMed]

33. Li, J.; Chen, M.; Cullen, D.A.; Hwang, S.; Wang, M.; Li, B.; Liu, K.; Karakalos, S.; Lucero, M.; Zhang, H.; et al. Atomically dispersed manganese catalysts for oxygen reduction in proton-exchange membrane fuel cells. Nat. Catal. 2018, 1, 935-945. [CrossRef]

34. Wei, H.; Liu, X.; Wang, A.; Zhang, L.; Qiao, B.; Yang, X.; Huang, Y.; Miao, S.; Liu, J.; Zhang, T. FeOx-supported platinum single-atom and pseudo-single-atom catalysts for chemoselective hydrogenation of functionalized nitroarenes. Nat. Commun. 2014, 5, 5634. [CrossRef] [PubMed]

35. Lang, R.; Xi, W.; Liu, J.-C.; Cui, Y.-T.; Li, T.; Lee, A.F.; Chen, F.; Chen, Y.; Li, L.; Li, L.; et al. Non defect-stabilized thermally stable single-atom catalyst. Nat. Commun. 2019, 10, 234. [CrossRef] [PubMed]

36. Qiao, B.; Wang, A.; Yang, X.; Allard, L.F.; Jiang, Z.; Cui, Y.; Liu, J.; Li, J.; Zhang, T. Single-atom catalysis of CO oxidation using Pt1/FeOx. Nat. Chem. 2011, 3, 634. [CrossRef] [PubMed]

37. Liu, J. Catalysis by supported single metal atoms. ACS Catal. 2017, 7, 34-59. [CrossRef]

38. Rivera-Cárcamo, C.; Serp, P. Single atom catalysts on carbon-based materials. ChemCatChem 2018, 10, 5058-5091. [CrossRef]

39. Jia, M.; Fan, Q.; Liu, S.; Qiu, J.; Sun, Z. Single-atom catalysis for electrochemical $\mathrm{CO}_{2}$ reduction. Curr. Opin. Green Sustain. Chem. 2019, 16, 1-6. [CrossRef]

40. Jiao, L.; Jiang, H.-L. Metal-organic-framework-based single-atom catalysts for energy applications. Chem 2019, 5, 786-804. [CrossRef]

41. Zhu, Y.P.; Guo, C.; Zheng, Y.; Qiao, S.-Z. Surface and interface engineering of noble-metal-free electrocatalysts for efficient energy conversion processes. Acc. Chem. Res. 2017, 50, 915-923. [CrossRef] [PubMed]

42. Pegis, M.L.; McKeown, B.A.; Kumar, N.; Lang, K.; Wasylenko, D.J.; Zhang, X.P.; Raugei, S.; Mayer, J.M. Homogenous electrocatalytic oxygen reduction rates correlate with reaction overpotential in acidic organic solutions. ACS Cent. Sci. 2016, 2, 850-856. [CrossRef] [PubMed]

43. Zhang, W.; Sherrell, P.; Minett, A.I.; Razal, J.M.; Chen, J. Carbon nanotube architectures as catalyst supports for proton exchange membrane fuel cells. Energy Environ. Sci. 2010, 3, 1286-1293. [CrossRef]

44. Sun, S.; Zhang, G.; Gauquelin, N.; Chen, N.; Zhou, J.; Yang, S.; Chen, W.; Meng, X.; Geng, D.; Banis, M.N.; et al. Single-atom catalysis using Pt/Graphene achieved through atomic layer deposition. Sci. Rep. 2013, 3, 1775. [CrossRef]

45. Yang, S.; Kim, J.; Tak, Y.J.; Soon, A.; Lee, H. Single-atom catalyst of platinum supported on titanium nitride for selective electrochemical reactions. Angew. Chem. Int. Ed. 2016, 55, 2058-2062. [CrossRef] [PubMed]

46. Chen, Y.; Ji, S.; Wang, Y.; Dong, J.; Chen, W.; Li, Z.; Shen, R.; Zheng, L.; Zhuang, Z.; Wang, D.; et al. Isolated single iron atoms anchored on $\mathrm{N}$-doped porous carbon as an efficient electrocatalyst for the oxygen reduction reaction. Angew. Chem. Int. Ed. 2017, 56, 6937-6941. [CrossRef]

47. Zhang, J.; Zhang, M.; Zeng, Y.; Chen, J.; Qiu, L.; Zhou, H.; Sun, C.; Yu, Y.; Zhu, C.; Zhu, Z. Single Fe atom on hierarchically porous $\mathrm{S}, \mathrm{N}$-codoped nanocarbon derived from porphyra enable boosted oxygen catalysis for rechargeable Zn-air batteries. Small 2019, 15, 1900307. [CrossRef] [PubMed]

48. Wan, X.; Liu, X.; Li, Y.; Yu, R.; Zheng, L.; Yan, W.; Wang, H.; Xu, M.; Shui, J. Fe-N-C electrocatalyst with dense active sites and efficient mass transport for high-performance proton exchange membrane fuel cells. Nat. Catal. 2019, 2, 259-268. [CrossRef]

49. Ma, L.; Chen, S.; Pei, Z.; Huang, Y.; Liang, G.; Mo, F.; Yang, Q.; Su, J.; Gao, Y.; Zapien, J.A.; et al. Single-site active iron-based bifunctional oxygen catalyst for a compressible and rechargeable Zinc-air battery. ACS Nano 2018, 12, 1949-1958. [CrossRef] 
50. Yi, J.-D.; Xu, R.; Wu, Q.; Zhang, T.; Zang, K.-T.; Luo, J.; Liang, Y.-L.; Huang, Y.-B.; Cao, R. Atomically dispersed Iron-Nitrogen active sites within porphyrinic triazine-based frameworks for oxygen reduction reaction in both alkaline and acidic media. ACS Energy Lett. 2018, 3, 883-889. [CrossRef]

51. Guo, Y.; Yuan, P.; Zhang, J.; Hu, Y.; Amiinu, I.S.; Wang, X.; Zhou, J.; Xia, H.; Song, Z.; Xu, Q.; et al. Carbon nanosheets containing discrete $\mathrm{Co}-\mathrm{Nx}$-By-C active sites for efficient oxygen electrocatalysis and rechargeable Zn-air batteries. ACS Nano 2018, 12, 1894-1901. [CrossRef] [PubMed]

52. Yu, H.; Fisher, A.; Cheng, D.; Cao, D. Cu,N-codoped hierarchical porous carbons as electrocatalysts for oxygen reduction reaction. ACS Appl. Mater. Interfaces 2016, 8, 21431-21439. [CrossRef] [PubMed]

53. Jia, N.; Xu, Q.; Zhao, F.; Gao, H.-X.; Song, J.; Chen, P.; An, Z.; Chen, X.; Chen, Y. Fe/N codoped carbon nanocages with single-atom feature as efficient oxygen reduction reaction electrocatalyst. ACS Appl. Energy Mater. 2018, 1, 4982-4990. [CrossRef]

54. Yang, Y.; Wang, C.; Gao, S.; Mao, K.; Xia, G.; Lin, Z.; Jiang, P.; Hu, L.; Chen, Q. Incorporation of Cu-Nx cofactors into graphene encapsulated $\mathrm{Co}$ as biomimetic electrocatalysts for efficient oxygen reduction Nanoscale 2018, 10, 21076-21086. [CrossRef]

55. Yang, Y.; Mao, K.; Gao, S.; Huang, H.; Xia, G.; Lin, Z.; Jiang, P.; Wang, C.; Wang, H.; Chen, Q. O-, $\mathrm{N}$-Atoms-coordinated $\mathrm{Mn}$ cofactors within a graphene framework as bioinspired oxygen reduction reaction electrocatalysts. Adv. Mater. 2018, 30, 1801732. [CrossRef]

56. Pan, Y.; Liu, S.; Sun, K.; Chen, X.; Wang, B.; Wu, K.; Cao, X.; Cheong, W.-C.; Shen, R.; Han, A.; et al. A bimetallic $\mathrm{Zn} / \mathrm{Fe}$ polyphthalocyanine-derived single-atom Fe-N4 catalytic site: A superior trifunctional catalyst for overall water splitting and Zn-air batteries. Angew. Chem. Int. Ed. 2018, 57, 8614-8618. [CrossRef] [PubMed]

57. Tang, C.; Wang, B.; Wang, H.-F.; Zhang, Q. Defect engineering toward atomic Co-Nx-C in hierarchical graphene for rechargeable flexible solid Zn-air batteries. Adv. Mater. 2017, 29, 1703185. [CrossRef]

58. Lai, Q.; Zheng, L.; Liang, Y.; He, J.; Zhao, J.; Chen, J. Metal-organic-framework-derived Fe-N/C electrocatalyst with five-coordinated Fe-Nx sites for advanced oxygen reduction in acid media. ACS Catal. 2017, 7, 1655-1663. [CrossRef]

59. Wang, X.X.; Swihart, M.T.; Wu, G. Achievements, challenges and perspectives on cathode catalysts in proton exchange membrane fuel cells for transportation. Nat. Catal. 2019, 2, 578-589. [CrossRef]

60. Fei, H.; Dong, J.; Arellano-Jimenez, M.J.; Ye, G.; Dong Kim, N.; Samuel, E.L.G.; Peng, Z.; Zhu, Z.; Qin, F.; Bao, J.; et al. Atomic cobalt on nitrogen-doped graphene for hydrogen generation. Nat. Commun. 2015, 6 . [CrossRef]

61. Hu, P.; Huang, Z.; Amghouz, Z.; Makkee, M.; Xu, F.; Kapteijn, F.; Dikhtiarenko, A.; Chen, Y.; Gu, X.; Tang, X. Electronic metal-support interactions in single-atom catalysts. Angew. Chem. Int. Ed. 2014, 53, 3418-3421. [CrossRef] [PubMed]

62. Li, C. Single Co atom catalyst stabilized in C/N containing matrix. Chin. J. Catal. 2016, 37, 1443-1445. [CrossRef]

63. Yin, P.; Yao, T.; Wu, Y.; Zheng, L.; Lin, Y.; Liu, W.; Ju, H.; Zhu, J.; Hong, X.; Deng, Z.; et al. Single cobalt atoms with precise N-coordination as superior oxygen reduction reaction catalysts. Angew. Chem. Int. Ed. 2016, 55, 10800-10805. [CrossRef] [PubMed]

64. Deng, D.; Chen, X.; Yu, L.; Wu, X.; Liu, Q.; Liu, Y.; Yang, H.; Tian, H.; Hu, Y.; Du, P.; et al. A single iron site confined in a graphene matrix for the catalytic oxidation of benzene at room temperature. Sci. Adv. 2015, 1. [CrossRef] [PubMed]

65. Liu, W.; Zhang, L.; Yan, W.; Liu, X.; Yang, X.; Miao, S.; Wang, W.; Wang, A.; Zhang, T. Single-atom dispersed Co-N-C catalyst: Structure identification and performance for hydrogenative coupling of nitroarenes. Chem. Sci. 2016, 7, 5758-5764. [CrossRef]

66. Bezerra, C.W.B.; Zhang, L.; Lee, K.; Liu, H.; Marques, A.L.B.; Marques, E.P.; Wang, H.; Zhang, J. A review of $\mathrm{Fe}-\mathrm{N} / \mathrm{C}$ and $\mathrm{Co}-\mathrm{N} / \mathrm{C}$ catalysts for the oxygen reduction reaction. Electrochim. Acta 2008, 53, 4937-4951. [CrossRef]

67. Chen, Y.; Ji, S.; Chen, C.; Peng, Q.; Wang, D.; Li, Y. Single-atom catalysts: Synthetic strategies and electrochemical applications. Joule 2018, 2, 1242-1264. [CrossRef]

68. Yang, Z.; Wang, Y.; Zhu, M.; Li, Z.; Chen, W.; Wei, W.; Yuan, T.; Qu, Y.; Xu, Q.; Zhao, C.; et al. Boosting oxygen reduction catalysis with Fe-N4 sites decorated porous carbons toward fuel cells. ACS Catal. 2019, 9, 2158-2163. [CrossRef] 
69. Niu, W.; Yang, Y. Amorphous MOF introduced N-doped graphene: An efficient and versatile electrocatalyst for Zinc-air battery and water splitting. ACS Appl. Energy Mater. 2018, 1, 2440-2445. [CrossRef]

70. Han, A.; Wang, B.; Kumar, A.; Qin, Y.; Jin, J.; Wang, X.; Yang, C.; Dong, B.; Jia, Y.; Liu, J.; et al. Recent advances for MOF-derived carbon-supported single-atom catalysts. Small Methods 2019, 3, 1800471. [CrossRef]

71. Zhao, R.; Liang, Z.; Gao, S.; Yang, C.; Zhu, B.; Zhao, J.; Qu, C.; Zou, R.; Xu, Q. Puffing up energetic metal-organic frameworks to large carbon networks with hierarchical porosity and atomically dispersed metal sites. Angew. Chem. 2019, 131, 1997-2001. [CrossRef]

72. Jiao, L.; Wan, G.; Zhang, R.; Zhou, H.; Yu, S.-H.; Jiang, H.-L. From metal-organic frameworks to single-atom Fe implanted N-doped porous carbons: Efficient oxygen reduction in both alkaline and acidic media. Angew. Chem. Int. Ed. 2018, 57, 8525-8529. [CrossRef] [PubMed]

73. Wang, J.; Huang, Z.; Liu, W.; Chang, C.; Tang, H.; Li, Z.; Chen, W.; Jia, C.; Yao, T.; Wei, S.; et al. Design of $\mathrm{N}$-coordinated dual-metal sites: A stable and active Pt-free catalyst for acidic oxygen reduction reaction. J. Am. Chem. Soc. 2017, 139, 17281-17284. [CrossRef] [PubMed]

74. Lu, Z.; Wang, B.; Hu, Y.; Liu, W.; Zhao, Y.; Yang, R.; Li, Z.; Luo, J.; Chi, B.; Jiang, Z.; et al. An isolated Zinc-cobalt atomic pair for highly active and durable oxygen reduction. Angew. Chem. 2019, 131, 2648-2652. [CrossRef]

75. Liu, D.; Wang, B.; Li, H.; Huang, S.; Liu, M.; Wang, J.; Wang, Q.; Zhang, J.; Zhao, Y. Distinguished $\mathrm{Zn}, \mathrm{Co}-\mathrm{Nx}-\mathrm{C}-\mathrm{Sy}$ active sites confined in dentric carbon for highly efficient oxygen reduction reaction and flexible Zn-air batteries. Nano Energy 2019, 58, 277-283. [CrossRef]

76. Chen, S.; Chen, S.; Zhang, B.; Zhang, J. The bifunctional oxygen electrocatalysis of N, S Co-doped porous carbon with interspersed hollow $\mathrm{CoO}$ nanoparticles for rechargeable $\mathrm{Zn}$-air batteries. ACS Appl. Mater. Interfaces 2019, 11, 16720-16728. [CrossRef] [PubMed]

77. Chen, P.; Zhou, T.; Xing, L.; Xu, K.; Tong, Y.; Xie, H.; Zhang, L.; Yan, W.; Chu, W.; Wu, C.; et al. Atomically dispersed Iron-Nitrogen species as electrocatalysts for bifunctional oxygen evolution and reduction Reactions. Angew. Chem. Int. Ed. 2017, 56, 610-614. [CrossRef] [PubMed]

78. Chen, Y.; Ji, S.; Zhao, S.; Chen, W.; Dong, J.; Cheong, W.-C.; Shen, R.; Wen, X.; Zheng, L.; Rykov, A.I.; et al. Enhanced oxygen reduction with single-atomic-site iron catalysts for a Zinc-air battery and Hydrogen-air fuel cell. Nat. Commun. 2018, 9, 5422. [CrossRef]

79. Liu, D.; Ding, S.; Wu, C.; Gan, W.; Wang, C.; Cao, D.; Rehman, Z.u.; Sang, Y.; Chen, S.; Zheng, X.; et al. Synergistic effect of an atomically dual-metal doped catalyst for highly efficient oxygen evolution. J. Mater. Chem. A 2018, 6, 6840-6846. [CrossRef]

80. Zang, W.; Sumboja, A.; Ma, Y.; Zhang, H.; Wu, Y.; Wu, S.; Wu, H.; Liu, Z.; Guan, C.; Wang, J.; et al. Single Co atoms anchored in porous $\mathrm{N}$-doped carbon for efficient Zinc-air battery cathodes. ACS Catal. 2018, 8, 8961-8969. [CrossRef]

81. Jasinski, R. A new fuel cell cathode catalyst. Nature 1964, 201, 1212-1213. [CrossRef]

82. Alt, H.; Binder, H.; Sandstede, G. Mechanism of the electrocatalytic reduction of oxygen on metal chelates. J. Catal. 1973, 28, 8-19. [CrossRef]

83. Zhang, W.; He, Y.-S.; Zhang, S.; Yang, X.; Yuan, X.; Ma, Z.-F. Effectively incorporating iron, nitrogen, and sulfur functionalities on carbon surface for a superior electrocatalyst toward oxygen reduction reaction. Electrochem. Commun. 2017, 81, 34-37. [CrossRef]

84. Liang, H.-W.; Wei, W.; Wu, Z.-S.; Feng, X.; Müllen, K. Mesoporous metal-nitrogen-doped carbon electrocatalysts for highly efficient oxygen reduction reaction. J. Am. Chem. Soc. 2013, 135, 16002-16005. [CrossRef] [PubMed]

85. Wang, Q.; Zhou, Z.-Y.; Lai, Y.-J.; You, Y.; Liu, J.-G.; Wu, X.-L.; Terefe, E.; Chen, C.; Song, L.; Rauf, M.; et al. Phenylenediamine-based FeNx/C catalyst with high activity for oxygen reduction in acid medium and its active-site probing. J. Am. Chem. Soc. 2014, 136, 10882-10885. [CrossRef]

86. Ma, Z.-F.; Xie, X.-Y.; Ma, X.-X.; Zhang, D.-Y.; Ren, Q.; Heß-Mohr, N.; Schmidt, V.M. Electrochemical characteristics and performance of CoTMPP/BP oxygen reduction electrocatalysts for PEM fuel cell. Electrochem. Commun. 2006, 8, 389-394. [CrossRef]

87. Wang, P.; Ma, Z.; Zhao, Z.; Jia, L. Oxygen reduction on the electrocatalysts based on pyrolyzed non-noble metal/poly-o-phenylenediamine/carbon black composites: New insight into the active sites. J. Electroanal. Chem. 2007, 611, 87-95. [CrossRef] 
88. Wu, J.; Zhou, H.; Li, Q.; Chen, M.; Wan, J.; Zhang, N.; Xiong, L.; Li, S.; Xia, B.Y.; Feng, G.; et al. Densely populated isolated single $\mathrm{Co}-\mathrm{N}$ site for efficient oxygen electrocatalysis. Adv. Energy Mater. 2019, 9, 1900149. [CrossRef]

89. Sun, T.; Zhao, S.; Chen, W.; Zhai, D.; Dong, J.; Wang, Y.; Zhang, S.; Han, A.; Gu, L.; Yu, R.; et al. Single-atomic cobalt sites embedded in hierarchically ordered porous nitrogen-doped carbon as a superior bifunctional electrocatalyst. Proc. Natl. Acad. Sci. USA 2018, 115, 12692-12697. [CrossRef]

90. Du, C.; Gao, X.; Chen, W. Recent developments in copper-based, non-noble metal electrocatalysts for the oxygen reduction reaction. Chin. J. Catal. 2016, 37, 1049-1061. [CrossRef]

91. Yang, L.; Cheng, D.; Xu, H.; Zeng, X.; Wan, X.; Shui, J.; Xiang, Z.; Cao, D. Unveiling the high-activity origin of single-atom iron catalysts for oxygen reduction reaction. Proc. Natl. Acad. Sci. USA 2018, 115, 6626-6631. [CrossRef] [PubMed]

92. Yang, Z.K.; Yuan, C.-Z.; Xu, A.-W. Confined pyrolysis within a nanochannel to form a highly efficient single iron site catalyst for Zn-air batteries. ACS Energy Lett. 2018, 3, 2383-2389. [CrossRef]

93. Wang, B.; Wang, X.; Zou, J.; Yan, Y.; Xie, S.; Hu, G.; Li, Y.; Dong, A. simple-cubic carbon frameworks with atomically dispersed iron dopants toward high-efficiency oxygen reduction. Nano Lett. 2017, 17, 2003-2009. [CrossRef] [PubMed]

94. Zhang, L.; Liu, T.; Chen, N.; Jia, Y.; Cai, R.; Theis, W.; Yang, X.; Xia, Y.; Yang, D.; Yao, X. Scalable and controllable synthesis of atomic metal electrocatalysts assisted by an egg-box in alginate. J. Mater. Chem. A 2018, 6, 18417-18425. [CrossRef]

95. Zhu, X.; Tan, X.; Wu, K.-H.; Chiang, C.-L.; Lin, Y.-C.; Lin, Y.-G.; Wang, D.-W.; Smith, S.; Lu, X.; Amal, R. N,P co-coordinated Fe species embedded in carbon hollow spheres for oxygen electrocatalysis. J. Mater. Chem. A 2019, 7, 14732-14742. [CrossRef]

96. Li, S.; Cheng, C.; Zhao, X.; Schmidt, J.; Thomas, A. Active salt/silica-templated 2D mesoporous FeCo-Nx-carbon as bifunctional oxygen electrodes for Zinc-air batteries. Angew. Chem. Int. Ed. 2018, 130, 1874-1880. [CrossRef]

97. Han, J.; Meng, X.; Lu, L.; Bian, J.; Li, Z.; Sun, C. Single-atom Fe-Nx-C as an efficient electrocatalyst for Zinc-air batteries. Adv. Funct. Mater. 2019, 8, 1808872. [CrossRef]

98. Yang, L.; Shi, L.; Wang, D.; Lv, Y.; Cao, D. Single-atom cobalt electrocatalysts for foldable solid-state Zn-air battery. Nano Energy 2018, 50, 691-698. [CrossRef]

99. Zhao, J.; Qin, R.; Liu, R. Urea-bridging synthesis of nitrogen-doped carbon tube supported single metallic atoms as bifunctional oxygen electrocatalyst for Zinc-air battery. Appl. Catal. B Environ. 2019, 256, 117778. [CrossRef]

100. Ji, D.; Fan, L.; Li, L.; Peng, S.; Yu, D.; Song, J.; Ramakrishna, S.; Guo, S. Atomically transition metals on self-supported porous carbon flake arrays as binder-free air cathode for wearable Zinc-air batteries. Adv. Mater. 2019, 31, 1808267. [CrossRef]

(C) 2019 by the authors. Licensee MDPI, Basel, Switzerland. This article is an open access article distributed under the terms and conditions of the Creative Commons Attribution (CC BY) license (http://creativecommons.org/licenses/by/4.0/). 